\title{
Variação Progressiva de Schoenberg em Hermeto Pascoal: análise e realização de duas lead sheets do Calendário do som
}

\author{
Fabiano Araújo (UFES, Vitória, ES) \\ armoniah@gmail.com \\ Fausto Borém (UFMG, Belo Horizonte, MG) \\ fborem@ufmg.br
}

\begin{abstract}
Resumo: Terceira parte de estudo relacionando Arnold Schoenberg e Hermeto Pascoal em relação à harmonia tonal. Aqui adaptamos e aplicamos os conceitos de Forma e Variação Progressiva de SCHOENBERG $(1994,2006)$, juntamente com outros conceitos (SCHOENBERG,1984, 1993, 1999, 2001, 2004) abordados em artigo anterior (ARAÚJO e BORÉM, 2013, às p.35-69 desse número de Per Musi) na realização de duas canções instrumentais do livro de partituras Calendário do som de Hermeto Pascoal: 23 de junho de 1996 (PASCOAL, 2000a, p.23), e 9 de Junho de 1997 (PASCOAL, 2000a, p.374), cujas partituras (PASCOAL, 2013a e 2013b) são apresentadas às p.96-98 e p.99-101 desse desse número de Per Musi.
\end{abstract}

Palavras-chave: Calendário do som de Hermeto Pascoal; teoria tonal de Arnold Schoenberg; análise da música popular brasileira e realização de cifras; variação progressiva na música popular.

\section{Schoenberg's Developing Variation on Hermeto Pascoal: analysis and realization of two lead sheets from Calendário do som}

\begin{abstract}
Third part of a study relating Arnold Schoenberg and Hermeto Pascoal with tonal harmony, this paper adapts and applies the concepts of Form and Progressive Variation by SCHOENBERG $(1994,2006)$, together with some other concepts (SCHOENBERG,1984, 1993, 1999, 2001, 2004) approached in a previous article (ARAÚJ0 e BORÉM, 2013, pp.35-69 of Per Musi this issue) in the realization of two instrumental songs from the scorebook Calendário do som by Brazilian multiinstrumentalist Hermeto Pascoal: 23 de junho de 1996 (PASCOAL, 2000a, p.23), and 9 de Junho de 1997 (PASCOAL, 2000a, p.374), which realized scores (PASCOAL, 2013a e 2013b) are also presented on pp.96-98 and p.99-101 of this Per Musi issue.
\end{abstract}

Keywords: Calendário do som by Hermeto Pascoal; tonal theory of Arnold Schoenberg; analysis of Brazilian popular music; lead sheet realization; developing variation in popular music.

\section{1 - Introdução}

Esse artigo é a terceira parte de um amplo estudo dos presentes co-autores, que articula a música de Hermeto Pascoal e a teoria musical tonal de Arnold Schoenberg. No primeiro trabalho, demonstramos como a história de vida de Hermeto Pascoal influiu diretamente na formação de suas diversas e ecléticas linguagens harmônicas (BORÉM e ARAÚJO, 2010, p.22-43; BORÉM e FREIRE, 2010, p.6379). Em seguida, revisamos e propomos uma adaptação dos Conceitos Tonais, Funções Tonais e Contextos Tonais de SCHOENBERG $(1993,1999,2001,2004,2006)$ à música popular (ARAÚJO e BORÉM, 2013, às p.35-69 do presente volume de Per Musi), especialmente em linguagens harmonicamente sofisticadas, como a de Hermeto Pascoal nas partituras do seu Calendário do Som (PASCOAL, 2000), duas das quais estão realizadas e editadas às p.96-98 e p.99-101 desse desse número de Per Musi (PASCOAL, 2013a e 2013b).

No presente artigo fazemos uma adaptação dos conceitos de Forma e Variação Progressiva de Schoenberg e propomos a aplicação deste referencial teórico na compreensão dos procedimentos composicionais de Hermeto Pascoal e sua performance, especialmente em relação à obtenção de linhas contrapontísticas seja na 
improvisação ou no arranjo. Para isso, selecionamos duas canções instrumentais do livro de partituras Calendário do som de Hermeto Pascoal para ilustrar essa abordagem: 23 de junho de 1996 (PASCOAL, 2000a, p.23) e 9 de Junho de 1997 (PASCOAL, 2000a, p.374).

0 conjunto de 366 peças do Calendário do som, bem como a maioria da vasta produção de Hermeto Pascoal, se associa à música tonal. Entretanto, seus procedimentos de afastamento e aproximação dos centros tonais, muito peculiares em relação à maioria dos músicos populares, assim como sua grafia única de cifras, revelam um pensamento estruturado que, se nasceram de sua intuição e autodidatismo enquanto músico brasileiro não letrado, encontram eco e explicação nos princípios sistematizados por outro importante compositor do século XX, o europeu Arnold Schoenberg, músico de formação acadêmica, racional.

A notação de Hermeto no Calendário do som é mais completa e criativa que a maioria dos outros compositores em suas lead sheets. Inclui, além das cifras, outros símbolos de interpretação como sinais de articulação, arpejos, efeitos como portamenti ou, ainda, anotações ao pé da página como "...tocar até cair no chão" (PASCOAL, 2000, p.66) cuja realização ele, com seu senso de humor, adverte: ". . . não escrevo andamento nem o estilo para não atrapalhar o digníssimo intérprete. Se vire" (PASCOAL, 2000, p.121). 0 intérprete da música de Hermeto Pascoal poderá também se fazer algumas perguntas ao buscar uma realização mais fundamentada no próprio estilo do compositor (o que inclui a realização de contrapontos e desenvolvimento motívico). Quando Hermeto não sugere arpejos nas cifras, deveríamos tocá-la em bloco? A análise da melodia poderia sugerir a utilização de notas, Motivos e Frases já existentes para gerar mais unidade na realização? As articulações originais da canção deveriam servir de material temático recorrente na realização?

Propomos aqui, que a realização da música de Hermeto Pascoal seja precedida por uma análise minuciosa e exaustiva. Entretanto, o leitor deve considerar análises mais simples, focada nos elementos mais relevantes e, por isso, talvez mais palatáveis e adequadas à rotina dos performers. Primeiro, recorremos a conceitos analíticos da teoria tonal de Schoenberg como Regiões, Acordes Vagantes, Permutabilidade Maior-Menor, Tonalidade Expandida, Tonalidade Flutuante e Tonalidade Suspensa. Esses conceitos, amplamente discutidos em nosso artigo anterior (ARAÚJO e BORÉM, às p.35-69 desse número de Per Musi), permitem uma visão mais aprofundada e prática sobre os afastamentos e aproximações tonais a serem aventados. Depois, visando ir além de uma realização dentro do senso comum da música popular, baseada nos clichês de improvisação (como os arpejos ou "sequência[s] de acordes do mesmo tipo" citados por ZAG0, 2007), recorremos também à noção de "rapsódia" de Schoenberg, o que nos permite aproximar a improvisação de um processo composicional mais estruturado. Finalmente, nos permitimos anotar os resultados que nos parecem mais satisfatórios, do ponto de vista musical, em forma de uma lead sheet realizada.

A realização que apresentamos consiste em reescrever a lead sheet a partir de dados da análise, como em um arranjo, mas ainda apresentado na forma de lead sheet. 0 objetivo é buscar elementos unificadores dentro da própria obra escrita para propor elementos de performance, criando introduções, grooves, pontes, linhas contrapontísticas, modificações na fórmula de certos compassos e até alargamento ou diminuição de certos trechos. Apresentaremos aqui os passos para elaboração da lead sheet de realização que foi usada para a gravação das canções instrumentais 23 de junho de 1996 e 9 de junho de 1997 no álbum Calendário do som - 9 dias (PASCOAL, 2009). Do processo de realização da lead sheet destacamos a produção de linhas cromáticas ou quase-diatônicas e as intervenções na forma. Se a teoria de harmonia tonal de Schoenberg é apresentada como meio pedagógico, partindo do contraponto para entender suas partes, os instrumentistas fizeram o caminho inverso, partindo da cifra para se chegar ao contraponto. Na realização das linhas contrapontísticas, os músicos recorreram a notas de passagem, bordaduras, apojaturas, escapadas, antecipações, suspensões, cromatismos e cambiatas. Essas linhas servem como esboço para a performance ( $e_{1}$ no caso de gravação, para cada take), observando-se os contornos melódicos e figuras rítmicas, as variações de expressão e técnica: dinâmicas, articulações, intenções.

Antes de prosseguir, discutimos mais alguns problemas em torno da partitura em formato lead sheet, característica marcante da escrita da musica popular, onde apenas informações básicas como linha melódica, cifras e ritmo harmônico e, esporadicamente algumas convenções, estão contidas. Vejamos a definição de LEVINE:

\footnotetext{
"Lead sheeté um pedaço de papel que contém uma linha melódica, acordes representados em símbolos e as vezes letra da música. Usualmente, a lead sheet traz o mínimo de informação, a maior parte em código, e essa informação, principalmente quanto aos acordes; não deve ser encarada do mesmo modo que as tábuas que Moisés trouxe da montanha." (LEVINE, 1995)
}

Vemos que, na prática de musica popular, estes elementos são como instruções para a performance, diferentemente da tradição de musica erudita, na qual o papel do intérprete é mais limitado e, geralmente, não se integra aos processos de compor, arranjar e, raramente, improvisar. Em sua revisão sobre a história da teoria do jazz, o musicólogo francês Laurent CUGNY (2009, p.155) relaciona este aspecto informal, sem rigor intelectual do discurso teórico que se formou ao redor da música popular, principalmente nos primeiros tempos deste discurso, como um "sintoma de um clima necessário para a improvisação" (CUGNY, 2009, p.154-155). É neste sentido que ele diz que, em relação à interpretação de lead sheets, "cada improvisador, no fundo, utiliza seu próprio sistema, sua maneira de apreender os sons especialmente a harmonia - o que mantém abertas suas chances de encontrar uma expressão própria". 
Em algumas anotações de pé de página das lead sheets do Calendário do som, podemos antever o processo amplamente integrado de composição-improvisaçãonotação-arranjo-realização de Hermeto Pascoal. Ele comenta: "Componho todas essas músicas na hora. De repente, cada dia é uma história. Viva o som!" (PASCOAL, 2000, p.88), ou "Como sempre, as minhas músicas começam com um estilo e terminam com vários. É conforme o dia e a cuca" (PASCOAL, 2000, p.84). Isso revela sua maleabilidade ao utilizar ferramentas comuns da improvisação como arpejos e sequência de acordes do mesmo tipo (ZAG0, 2007, p.3). Algumas vezes, Hermeto sugere uma instrumentação, como na música 19 de setembro de 1996: "Escrevi esta música brejeira com um instrumento bem diferente, que foi o flugelhorn. É parecido com o trompete, só que o som é mais aveludado" (PASCOAL, 2000, p.111). Para o cavaquinho, ele dedica pelo menos quatro músicas: (1) para a música 15 de setembro de 1996 ele diz "...compus esta música com o cavaquinho, estava com muita vontade de tocar com ele" (PASCOAL, 2000, p.107), (2) para a música 4 de outubro de 1996 diz "...ficou bem no estilo dele" (PASCOAL, 2000, p.126), (3) para a música 12 de dezembro de 1996 também se inspirou nesse instrumento (PASCOAL, 2000, p.195); (4) e em 29 de dezembro de 1996 junta o cavaquinho com o piano: "Esta deu um trabalho danado, porque eu compus com o cavaquinho pensando em uma harmonia. Quando cheguei ao piano me veio uma harmonia completamente estranha, claro no bom sentido!" (PASCOAL, 2000, p.212).

Esse caráter intuitivo, improvisatório e livre destas composições (escritas em formato lead sheet) de Hermeto Pascoal nos remete às mesmas características da forma musical rapsódica, apontadas por SCHOENBERG (2004, p.198) no seu Funções Estruturais da Harmonia:

\begin{abstract}
0 nome "rapsódia" sugere uma improvisação. [...] A excelência de uma improvisação assenta-se mais em seu inspirado imediatismo e vivacidade do que em sua elaboração. É claro, a diferença entre uma composição escrita e uma improvisada é a velocidade de produção, assunto este, relativo. Assim, sob condições apropriadas, uma improvisação pode ter a profundidade de elaboração de uma composição cuidadosamente trabalhada. Geralmente, uma improvisação irá apegar-se ao seu tema mais pelo exercício da imaginação e emoção do que, propriamente, das faculdades estritamente intelectuais. Haverá uma abundancia de temas e ideias contrastantes cujo efeito total se adquire por meio de rica modulação a regiões remotas. A conexão entre temas de naturezas tão diferenciadas e o controle da tendência centrífuga da harmonia são, em geral, obtidos de maneira apenas casual, por meio de "pontes", e inclusive, justaposições abruptas.
\end{abstract}

Estas considerações nos conduzem à três noções de improvisação na música popular. Primero, a "improvisação escrita", categoria na qual consideramos a escrita de Hermeto no Calendário do som. Segundo, o ato de "improvisar uma composição em performance", que é a tendência contemporânea (a chamada música improvisada) e da qual nasce a polêmica sobre seu pertencimento ou não ao nome jazz. Terceiro, a noção tradicional de improvisação: um instrumentista solista improvisando sobre a harmonia de um standard em um ou mais chorus.
Na nossa visão, Hermeto, ao escrever suas composições improvisadas no formato lead sheet, cria uma obra que, num primeiro momento é ao mesmo tempo "fechada", "definitiva" e "independente" (por ser escrita), mas "aberta" em seu processo de criação (por conter traços de técnicas de improvisação). Em um segundo momento, nas mãos do intérprete que a realiza, este pode escolher de não seguir o processo de leitura/interpretação voltado para a imitação dos padrões estilísticos presentes nas obras gravadas de Hermeto, ou dos padrões tradicionais do jazz (tema-solostema; solista/seção rítmica; etc...). Pode, ao contrário, partir para um mergulho no "texto musical" deixado na lead sheet como fonte única para a interpretação do que chamamos de "ideia musical", no sentido shoenberguiano. Com os conceitos desenvolvidos por Schoenberg, propomos um modelo de compreensão do texto musical deixado por Hermeto para estruturar "improvisações-composições" na sua realização de modo a incluir procedimentos mais utilizados na música erudita (como a Variação Progressiva) mas cumprindo formalmente o percurso da forma (intro, seções, pontes, solos, coda), se aproximando muito das características do Arranjo.

Com a publicação dessas duas lead sheets realizadas (PASCOAL, 2013a e 2013b, às p.96-98 e p.99-101 desse número de Per Musi), propomos ao músico popular experimentar um nivel mais estruturado e sofisticado nas suas improvisações (nos três sentidos evocados acima). Por outro lado, convidamos também o músico erudito a se aproximar destas práticas que na maioria das vezes, Ihe parece fascinante e tão distante, como explicitado pelo pianista Nelson Freire: "Olha, eu tenho inveja de quem saber tocar jazz, incrível. . sabe uma coisa que eu adoraria? Chega assim e, de repente. . . improvisar...eu tenho fascinação por Errol Garner. .. nunca vi ninguém com tanto prazer. .." (FREIRE e SALLES, 2003, em [01:06:46]).

\section{2 - Schoenberg e a apresentação da ideia musical}

Os conceitos de Schoenberg sobre elementos da Forma podem ser melhor compreendidos a partir de seus manuscritos inacabados, editados após sua morte em obras como Coherence, counterpoint, instrumentation, instruction in form (SCHOENBERG, 1994) e The Musical idea, the logic and the art of its presentation (SCHOENBERG, 2006). Neles, Schoenberg quiz evidenciar a unidade e compreensibilidade musical de uma peça a partir da articulação de repetições e variações de uma ideia musical enquanto organismo vivo, em outras palavras, a Darstellung ou "...a apresentação de um objeto a um espectador de modo que ele perceba as partes compostas como se fosse um movimento funcional" (SCHOENBERG, 2006, p.2).

0 conceito de Grundgestalt (Motivo Básico ou Configuração básica) evoluiu ao longo da obra de Schoenberg, sendo fundamental no seu sistema de composição dodecafônico. DUDEQUE (2005, p.135, 141) fala da preocupação de Schoenberg em formular um 
princípio de unificação e articulação musical mesmo após o abandono da tonalidade:

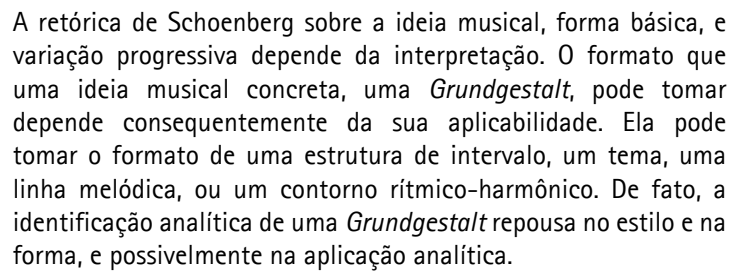
variação progressiva depende da interpretação. 0 formato que uma ideia musical concreta, uma Grundgestalt, pode tomar depende consequentemente da sua aplicabilidade. Ela pode tomar o formato de uma estrutura de intervalo, um tema, uma linha melódica, ou um contorno rítmico-harmônico. De fato, a identificação analítica de uma Grundgestalt repousa no estilo e na forma, e possivelmente na aplicação analítica.

Já o conceito de Variação Progressiva, por sua vez, é usado por Schoenberg como técnica composicional desde suas primeiras composições tonais e consiste basicamente do desenvolvimento progressivo de uma ideia ou forma básica que produz relações de unificação, em vários níveis, entre os demais elementos de uma peça musical.

Para compreender a forma segundo o pensamento de Schoenberg, são importantes - além de Grundgestalt e Variação Progressiva - outros conceitos descritos por ele como Motivo, Frase, Tema, Sentença, Período, Formações Estáveis e instáveis, Ideias Principais e Subordinadas.

\section{3 - A canção instrumental 23 de Junho de 1996}

A valsa-canção 23 de Junho de 1996 é a primeira das 366 composições do Calendário do Som. No alto da página 0 autor indica o local (Rio de Janeiro, bairro Jabour) e o título da música como em um calendário "Música escrita no dia 23 de Junho de 1996 - Hermeto Pascoal. Domingo". Na parte de baixo da partitura, ele escreve: "Terminei à 0 hora $47 \mathrm{~m}$. Viva o som, tudo de bom. sempre. Hermeto Pascoal. A vida é linda porque estamos todos sempre juntos." Não há indicação de andamento, mas vemos alguns sinais de articulação, como portamentinos c.8, 9, 15 e 17; e acentos e ligaduras de expressão, no c.13. Quanto à forma, temos um ritornelo curiosamente desenhado em forma de ave, e a indicação das casas I e II. Nos c.9, 11,15-19, Hermeto indica o ritmo harmônico dos acordes, cujas cifras serão comentadas mais abaixo. Seu esquema analítico completo é apresentado no Ex.53 ao final do artigo.

\section{1 - Variação Progressiva em 23 de Junho de 1996}

\section{Frase Inicial:}

A Frase 1 é estruturada na região da $t_{\text {, em sete }}$ compassos, como modelo-sequência e cadência (Ex.1). Os dois primeiros compassos da peça nos dão uma pista da Ideia Básica do tema com os Motivos a e $\boldsymbol{b}$. Estruturado sobre o I grau da t (Lá-menor), o Motivo a é formado por uma figura de 3 semínimas (Figura K), e apresenta um intervalo de $3^{\mathrm{a}} \mathrm{M}$ desc. (Mi-Dó) retornando para Mi por graus conjuntos. (Mi-Dó-Ré-[Mi]). 0 Motivo $\boldsymbol{b}$ também em semínimas, se inicia com um intervalo de $6^{\mathrm{a}} \mathrm{m}$ asc., retornado no sentido oposto por grau conjunto até a nota Lá. Estes dois motivos formam uma estrutura coerente, cujas características são repetidas e variadas ao longo da peça e, por isso, os dois formam a Gestalt A. Além de manterem a mesma figura ritmica de 3 semínimas (Figura K), os intervalos $\boldsymbol{a} \mathbf{1}$ e $\boldsymbol{b} \mathbf{1}$ podem ter sua origem no espelhamento das notas Dó-Ré no c. 1 no Dó-Si do c.2.

Percebe-se na estrutura da Frase 1, conexões e organizações que geram uma continuidade do discurso, desde as menores estruturas (Motivos) até as maiores (Gestaltes). 0 Intervalo a1 ( $3^{\mathrm{a}} \mathrm{M}$ desc.) do Motivo a é variado progressivamente e alternadamente (3a $\mathrm{M}$ desc; 6am asc; 5a desc.; 7aM asc). Do ponto de vista das características motivicas rítmicas, encontramos as figuras $X, Y$ e $Z$ progressivamente variadas a partir de $K$ (Ex.2), sendo $X$, variada por condensação de $K_{1}$ enquanto $Y$ e $Z$ são variadas por substituição: na primeira, as três primeiras colcheias de $\boldsymbol{X}$ por uma semínima pontuada; e na segunda, 4 colcheias por uma mínima.

FRASE INICIAL

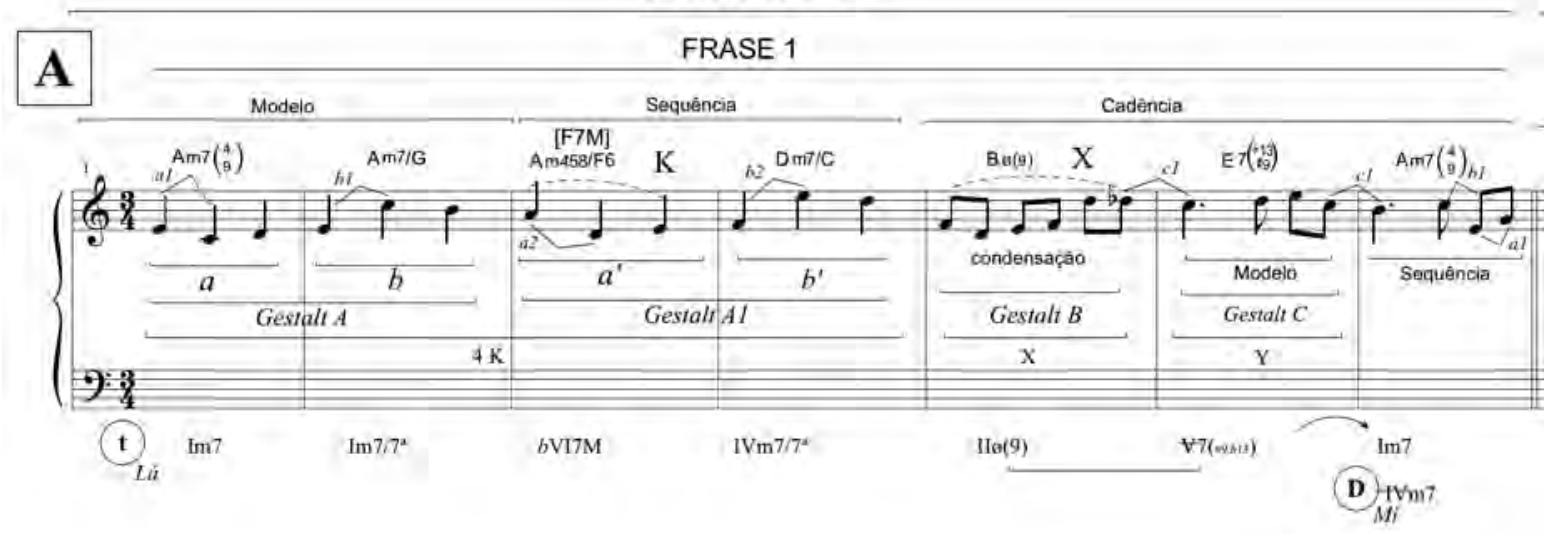

Ex.1- Estrutura, Motivos e Gestaltes da Frase 1, c.1-7 em 23 de junho de 1996 de Hermeto Pascoal. 


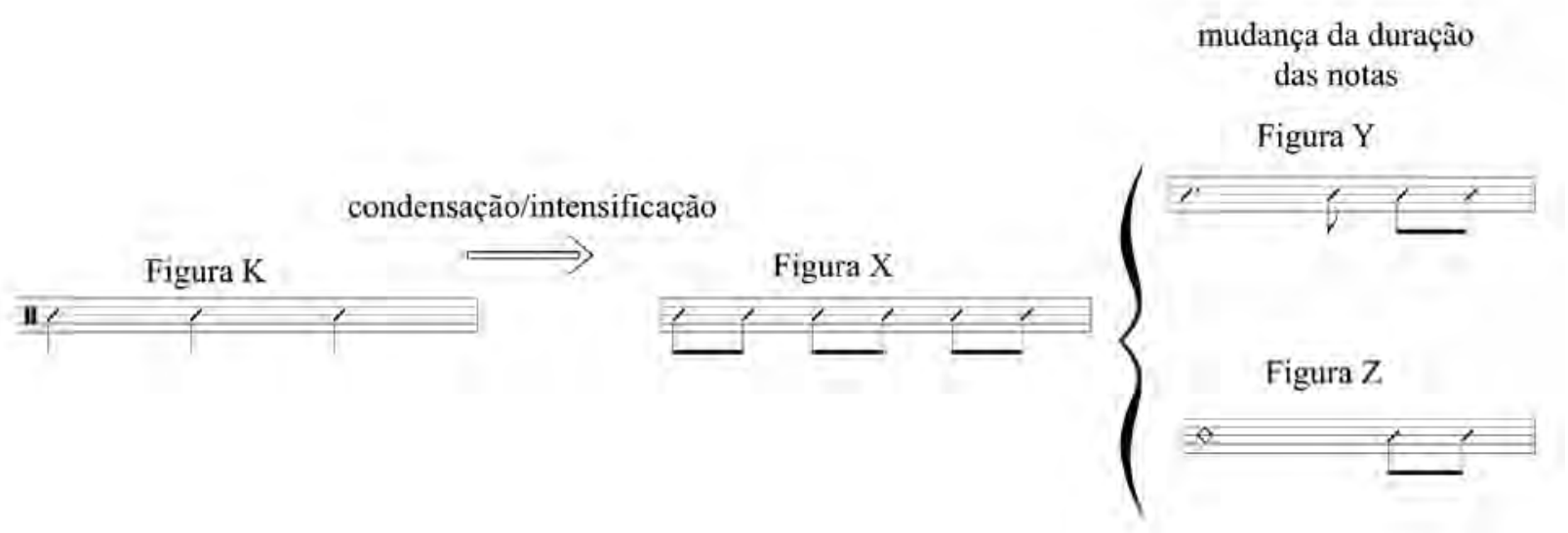

Ex.2 - Variação Progressiva das figuras ritmicas em 23 de junho de 1996 de Hermeto Pascoal.

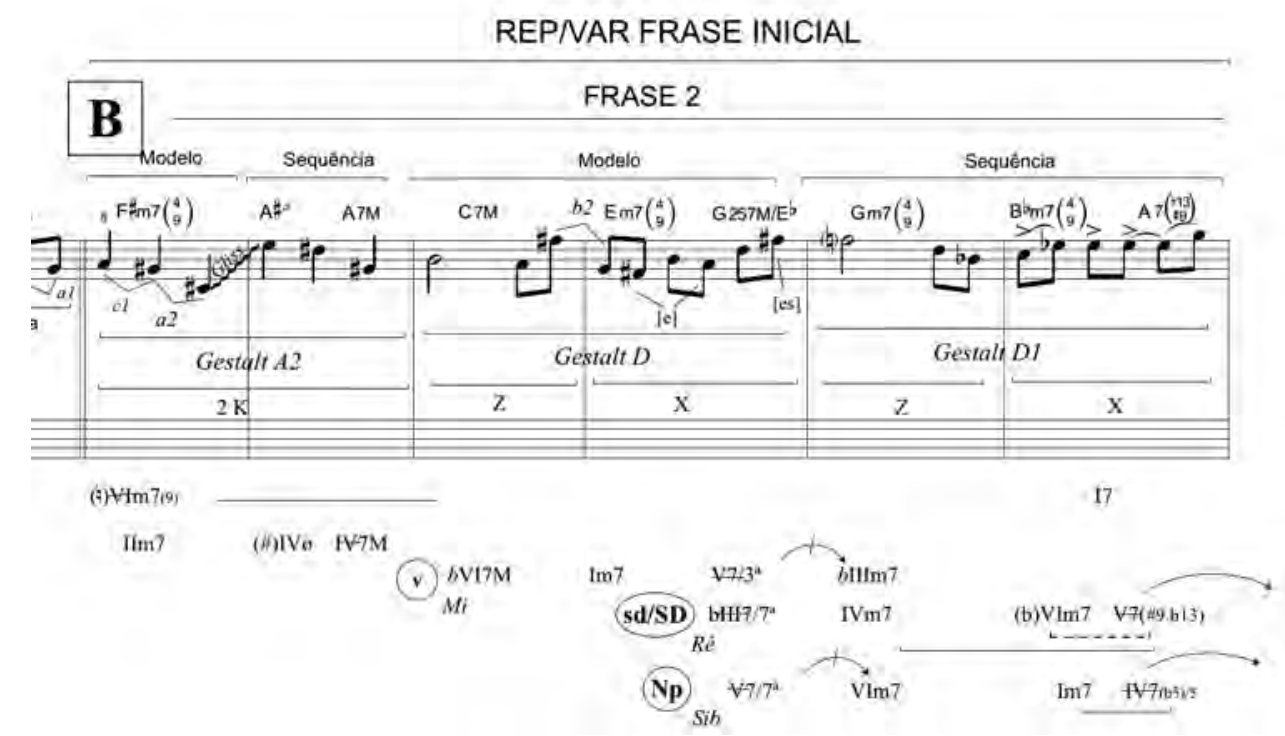

Ex.3- Estrutura, motivos e Gestalts da Frase 2, c.8-13 em 23 de junho de 1996 de Hermeto Pascoal.

Percebe-se nesta frase um procedimento de extensão da Gestalt $A$, usada como modelo para a elaboração da sequência (c.3-4) e um procedimento de conclusão com a cadencia (c.5-7), nitidamente elaborada como produto da condensação da Gestalt $A$.

A sequência identificada como Gestalt $A 1$, resulta inicialmente da repetição da Gestalt $\boldsymbol{A}$ uma $4^{\mathrm{a}}$ justa

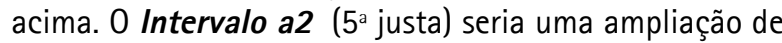
a1 (3 $3^{\text {a }}$ maior) e o Intervalo b2 (7० maior) uma ampliação de $\boldsymbol{b} 1$ (6a maior). Esta variação da Gestalt $\boldsymbol{A}$ é importante porque duas de suas caracteristicas, os intervalos a2 e $\boldsymbol{b} 2$, serão aproveitadas na estruturação de novas formasmotivo (Gestalts) nas próximas frases.

Na cadência (c.5-6) tem início o processo de dissolução das características da Gestalt $\boldsymbol{A}$. Incialmente ela é condensada, dissolvendo a Figura $K$, e trazendo à luz a Figura $X$ (semicolcheias) e o Motivo c1 (2 $2^{\text {a }}$ menor) na
Gestalt B resultante. No c.6 percebe-se a Figura $Y$ como derivada de $\boldsymbol{X}$ com a modificação da duração da primeira nota para uma semínima pontuada. A força desta nova forma-motivo (Gestalt $C$ ) é comprovada pela repetição de sua característica rítmica, representada pela Figura $Y$ no c.7. Este compasso é um ponto chave da continuidade do discurso devido ao uso da harmonia Am7 como ponto de chegada da t e como IV grau da sd. A sensação de ponto de chegada é dada claramente pela cadência, e a continuidade se dá pelo aproveitamento da função subdominante menor do IV grau com repetição da Figura $Y$ e a variação do contorno melódico da Gestalt $B$ através dos Motivos a 1 e $\boldsymbol{b} 1$ da Gestalt A.

Repetição e variação da Frase Inicial:

No Ex.3 mostramos a Frase 2 como uma repetição e variação (REP/NAR) da Frase Inicial. 0 inicio da Frase 2 é tomado como modelo/sequência que reapresenta eventos motívicos da Frase 1 , como a Figura $K$, e os intervalos c1 e 
b2. Ressalta-se aqui a repetição e combinação de elementos variados progressivamente a partir da forma básica Gestalt $\boldsymbol{A}_{1}$ que vai se consolidando assim como a Ideia Básica (Grundgestalt) . Nos c.10-11, define-se a Gestalt $D$, que pode ser vista como a soma da Figura $Z$ e da Figura $\boldsymbol{X}$ (a primeira entendida como Variação Progressiva da Figura $K$ através de $\boldsymbol{Y}$ ). A primeira parte (c. 10) da Gestalt $\boldsymbol{D}$ apresenta como elementos recorrentes da Frase 1, os intervalos b1 e b2, além do fato da passagem (Lá-Fá\#-Sol) delinear uma escapada por salto. A segunda parte (c.11) tem como base um arpejo da tríade de Sol maior, cujas notas são conectadas por escapadas (Sol-Fá\#-Si), (Si-Lá-Ré) e finalmente uma escapada por salto para alcançar a nota Fá do c.12 (RéFá\#-Fá). A sequência da Gestalt $\boldsymbol{D}$ (c.13) possui mais afinidade rítmica do que melódica.

A estrutura do tema (Ex.4) pode ser compreendida, portanto, segundo o modelo de Forma-Sentença (forma aberta) (Ex.5), com uma Frase Inicial, Frase 1 (c.1-7); uma repetição variada da Frase inicial, Frase 2 (c.8-13); uma terceira parte, Frase 3, constituída de uma repetição e variação de excertos das duas primeiras frases (c.1416); e uma cadência, Frase 4 (c.14 em diante).

\section{2 - Harmonia em 23 de Junho de 1996}

Essa valsa-canção em Lá menor tem apenas cinco tipos de acordes: a) Xm7 $\left({ }_{9}^{4}\right)$; b) X7M; c) X7M ${ }^{(\# 11)}$; d) Xm7(b5); e) $X 7\left({ }^{\# 13}{ }_{b 13}\right)$; e 2 tipos de estruturas de vozes: a) X458/Y6; e b) $\mathrm{X} 257+/ Y$. 0 tema é construido (e repetido) ao longo de 19 compassos, partindo da Região da t (Lá menor), e finalizado com Coda de dois compassos em uma Região remota que pode ser interpretada como a Np (Sib maior) ou, talvez, a SDNp (Mib maior).

$\mathrm{Na}$ organização das partes desta Forma-Sentença, a Frase 1 é estruturada na Região da t; a Frase 2, na Região da D passando pela intermediária [v] até a sd/SD. No fim da Frase 2, a tonalidade se mostra flutuante entre a sd/ SD e Np e no início da Frase 3, entre a T e a sd/SD e entre a t e a $M$. A Frase $\mathbf{4}$ faz o retorno à $t$ através de acordes transformados com influência da $\mathrm{M}$ e sd/SD e $\mathrm{Np}$ (no c.18), ou de expansão de Acordes Vagantes por Omissão do Caminho. A Coda reforça a possível influência da Np quando analisada com SDNp, onde o último acorde do c.18 (Abm7) é analisado não por Omissão do Caminho, mas como IVm resolvendo plagalmente em Eb7M após ser prolongado pelo acorde napolitano E7M.

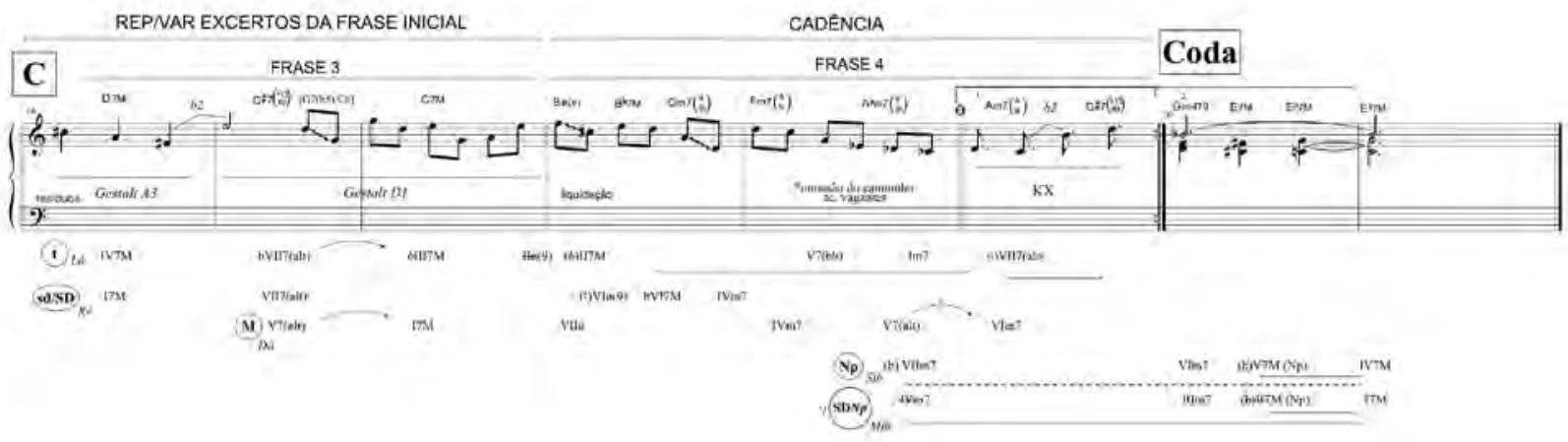

Ex.4 - Estrutura, Motivos e Gestalts da Frase 3 e Frase 4, c.14-19 em 23 de junho de 1996 de Hermeto Pascoal.

\begin{tabular}{|c|c|c|c|}
\hline \multicolumn{4}{|c|}{ Sentença } \\
\hline Frase inicial & $\begin{array}{c}\text { Repetição } \\
\text { e } \\
\begin{array}{c}\text { variação de Frase } \\
\text { inicial }\end{array} \\
\end{array}$ & $\begin{array}{c}\text { Repetição e variação } \\
\text { de excertos das duas } \\
\text { primeiras frases }\end{array}$ & Cadência \\
\hline Frase 1 & Frase 2 & Frase 3 & Frase 4 \\
\hline c. $1-7$ & c. $8-13$ & c. $14-16$ & c. $17-19 / /[21]$ \\
\hline$t$ & $\begin{array}{c}D-[v]-s d / S D \\
N p \\
\operatorname{SDNp}(*)\end{array}$ & $\mathrm{SD} / \mathrm{sd}-[\mathrm{M}]$ & $\begin{array}{c}{[\mathrm{M}]-\mathrm{t}} \\
\text { l/Np-SDNp (*) }\end{array}$ \\
\hline & $\begin{array}{r}\text { tor } \\
\text { fle }\end{array}$ & $\begin{array}{l}\text { lade } \\
\text { nte }\end{array}$ & \\
\hline
\end{tabular}

Ex.5 - Estrutura do Tema em em 23 de junho de 1996 de Hermeto Pascoal. 
A passagem entre a Região do $v$ e da sd/SD nos c.1112 , é produzida pelo acorde $\mathrm{G} 257 \mathrm{M} / \mathrm{Eb}$, interpretado com B7(alt)/D\# no v e como F7(b5)/Eb na sd. Nesta região, o acorde $\mathrm{Gm} 7$ seria um Prolongamento de $\mathrm{Bb} 7 \mathrm{M}$, mas na Np é possivel compreender F7 - Gm7 como uma cadência deceptiva. Buettner prevê essa relação como clichê de resolução, onde um acorde Dominante resolve um tom acima. 0 autor baseia essa resolução sob o prisma da

(...) possibilidade de respostas cadenciais em relação às tônicas relativa e anti-relativa, que possuem notas em comum com a tônica, o que possibilita a Dominante original resolver nesses outros dois acordes, além da própria tônica (BUETTNER, 2005, p,18)

Com isso, o acorde $\mathrm{Gm} 7$ pode ser preparado pela Dominante do seu relativo $\mathrm{Bb} 7 \mathrm{M}$, que seria exatamente 0 acorde F7.

No c. 13, a relação entre os acordes Bbm7 e A7 apresenta outro caso típico de Tonalidade Expandida. $0 \quad \forall 7$ (A7) apresenta-se como Acorde Vagante de sexta italiana. Esse acorde possui função múltipla, pois pode assumir a configuração de Eb7 $(9,13)$. 0 acorde Bbm7 provém dos procedimentos de expansão ${ }^{1}$, onde um Acorde Vagante é precedido pelo II grau cadencial de seus correspondentes.

A relação entre os acordes do c.18 provém do procedimento de expansão chamado Omissão do Caminho ${ }^{2}$. Aqui, a progressão Fm7 Abm7 $\square$ Am7 G\#7 | deve ser interpretada como derivação da progressão $\square \mathrm{Fm} 7 \mathrm{G} 7$ (alt) $\square$ Am7 G\#7|. Nessa cadência deceptiva, o acorde G7(alt) é um Acorde Vagante (Acorde de sexta italiana), de função múltipla, correspondente de Db7. Conforme os procedimentos de expansão, o Acorde Vagante é precedido pelo II grau cadencial de seu correspondente, e depois ocorre a Omissão do Caminho expandida (Ex.6).

\section{3 - Realização de 23 de Junho de 1996}

Criação de linhas cromáticas ou quase-diatônicas: A conceituação estabelecida por SALZER (1982) sobre Estrutura e Prolongamento, se aplicada sobre os elementos levantados pela análise schoenberguiana, poderá nos auxiliar na utilização prática dos elementos retirados da análise. Para ele, o conceito de estrutura e
Prolongamento é o principal fator sobre o qual a coerência tonal é baseada. Essa ideia sugere que um organismo musical fundamenta-se sobre uma estrutura que delineia um movimento com direcionamento específico para um centro. Essa base estrutural representa a opção de caminho mais direto percorrido pela ideia musical. Porém, o interesse e tensão de uma peça musical, consistem na expansão, modificação, distorção e elaboração dessa direção básica. Esses efeitos são obtidos através dos diferentes tipos de Prolongamentos.

Por exemplo, no c.8 (Ex.7), pode-se prolongar o acorde F\#m7 (IIm grau), envolvendo-o com Acordes Vagantes. Através dessa análise, o músico poderá enxergar possiveis direções para as vozes de acordo com a transformação analisada, e assim, recorrer simultaneamente a uma suavização e sofisticação harmônicas nas mudanças de Região. Além disso, o Prolongamento com Acordes Vagantes produz o efeito de suspensão da tonalidade, "realçando", ou "turvando" as passagens, como se estivéssemos trabalhando com atmosferas, num jogo de luzes e sombras em uma cena. ${ }^{3}$ No Ex.7, a conexão entre o IVm7 (Am7) e o IIm (F\#m7) foi prolongada com a transformação do IVm7 em Acorde Vagante. Esse Prolongamento pode ser obtido rapidamente através dos clichês de resolução propostos por BUETTNER (2005, p.17-30) ${ }^{4}$. Os acordes Dominantes da tônica relativa (D7M) e da anti-relativa (A7M) de F\#m podem lhe oferecer respostas cadenciais. Assim, obtemos os acordes A7 e seu correspondente Eb7, que resolveriam na relativa, e os acordes E7 e B7, que resolveriam na anti-relativa. A partir desses acordes, escolhemos aquele que, com a nota da melodia na voz principal, assegure um Acorde Vagante correspondente às coleções do Sistema de Correspondência dos Acordes Vagantes ${ }^{5}$. Com essa rápida "estratégia", obtém-se o acorde $\operatorname{Eb7}(9$, \#11), que na análise schoenberguiana é uma transformação do IV grau Am7 no acorde $A 7(b 5) / E b$. Com isso, tiramos proveito de suas possibilidades de múltiplo direcionamento das vozes $^{6}$. Depois do $\mathrm{F \# m}$, introduzimos o I grau transformado E7 $(69, \# 11,13)$ para chegar ao A7M (c.9), que havia sido prolongado pelo $A \# \varnothing$. Aqui, propomos uma linha que faz a antecipação do baixo A\#, e que acaba por diferir da convenção rítmica da partitura original.

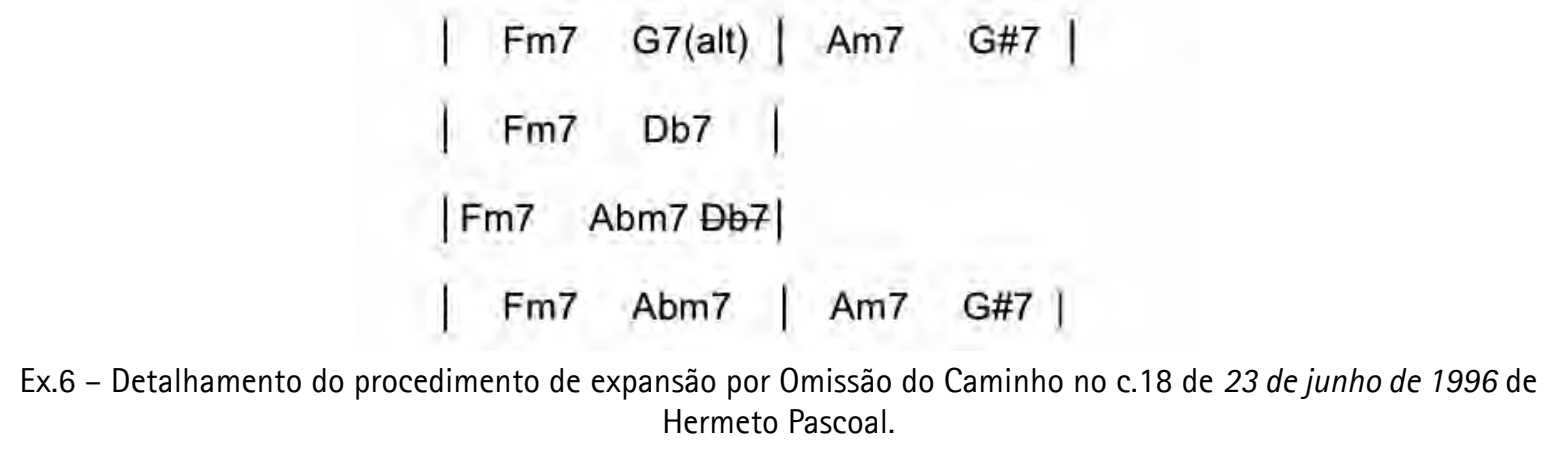




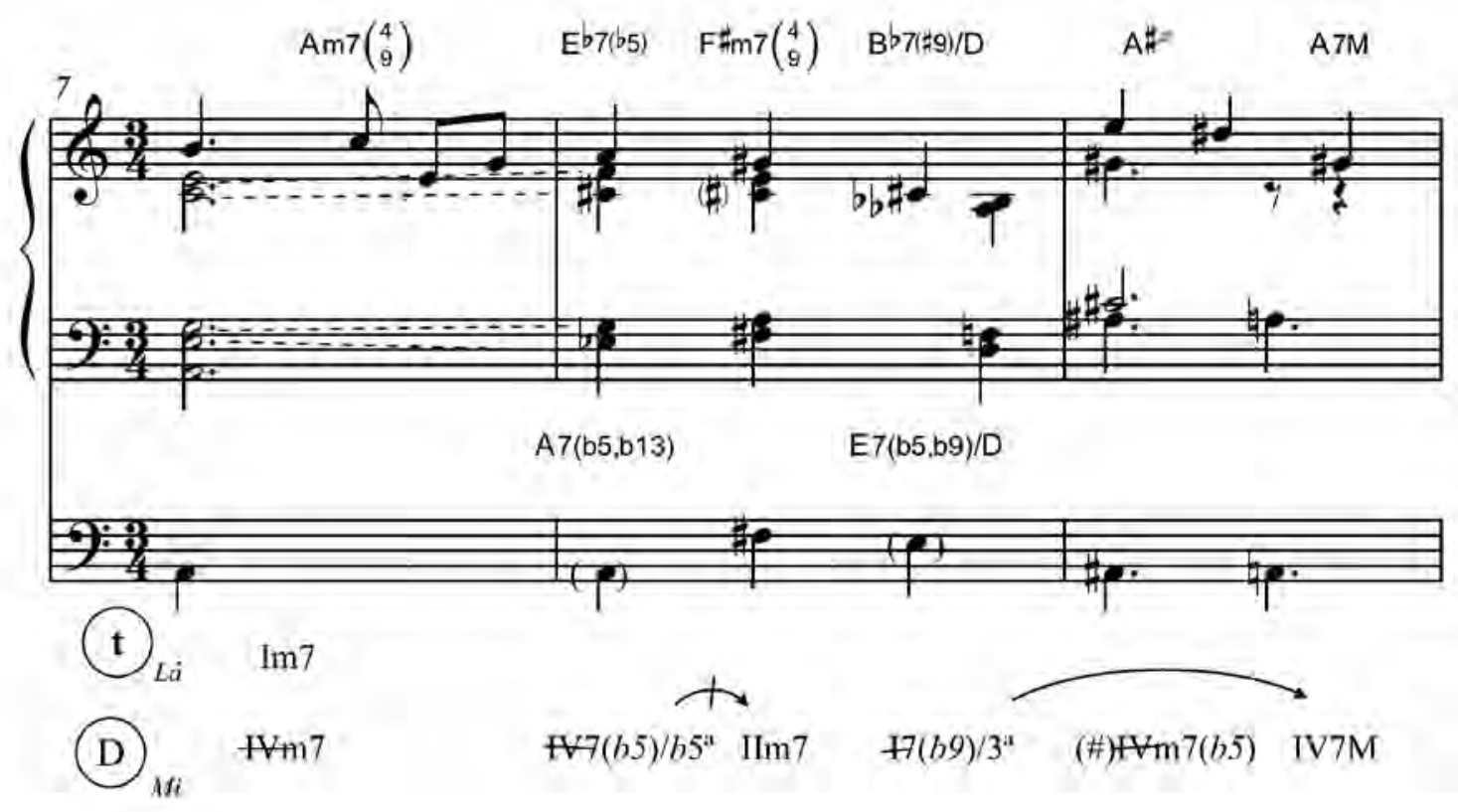

Ex.7 - Inserção das Harmonias Vagantes A7 $(b 5, b 13)$ e E7 $(b 5,69) / D$ em 23 de junho de 1996 de Hermeto Pascoal.

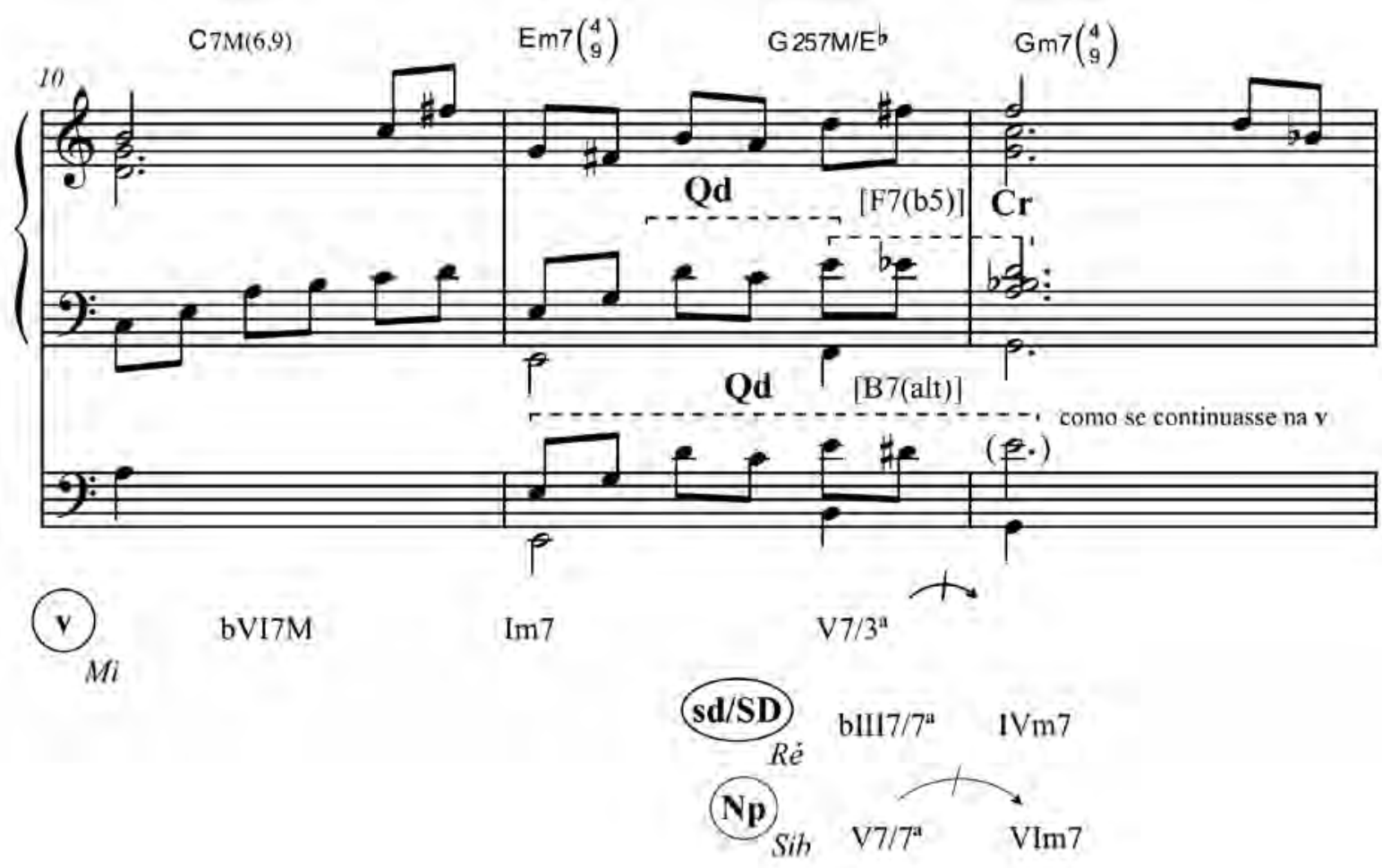

Ex.8- Linhas contrapontísticas nos c.10-12 de 23 de junho de 1996 de Hermeto Pascoal.

0 Ex.8 mostra como uma mudança de função leva à mudança de direcionamento de uma voz. No terceiro tempo do c.11, a terça do acorde B7 foi alcançada quase-diatônicamente caracterizando-se como sensivel (Ré\#) da Região v (Mi menor) admitindo, assim, seu direcionamento ascendente. Com a constituição vagante

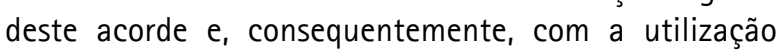

de suas funções múltiplas, o direcionamento da nota Ré\# passa a ser descendente, uma vez que esta é enarmonizada com Mib, e funcionando como sétima menor de F7, bVII7, grau expandido do acorde Gm7. Na elaboração das linhas contrapontísticas, o baixo define as fundamentais dos Acordes Vagantes B7 e F7. 0 Mib enarmônico de Ré\# foi usado no tenor, sendo alcançado 
por uma escapada (Ré-Dó-Mi) que desenha também uma cambiata (Ré- [Dó]-Mi-Mib). Na linha cromática de passagem (Sol-Sol\#-Lá), na voz contralto, o Sol\# é a nona de um F\#ø/A que cadencia (Prolongamento) o B7.

Nos c.13-17 (Ex.9), a Região Intermediária SD direcionase para o I grau da M. A harmonia desse trecho é um Prolongamento do IV grau de Lá-menor. Além disso, esses acordes foram individualmente prolongados. Com isso, gerou-se uma linha contrapontística cromática, que alcança a terça maior do acorde de Dó-maior, no c.16. A linha cromática foi alcançada através do direcionamento das sensiveis dos acordes. 0 acorde Bbm7 do c.13 pode ser visto como um Prolongamento do Acorde Vagante A7. Esse Prolongamento foi obtido através do procedimento de expansão que implica na colocação de um acorde de Subdominante de um dos correspondentes do A7. Em seu contexto original, a sétima do Bbm7 direciona-se descendentemente para a terça do Eb7. Com isso, obtemos o movimento descendente da nota Láb para Sol (sétima do A7), que naturalmente descende para a terça do D7M. 0 direcionamento descendente da terça do I grau da SD
(D7M) é justificável uma vez que essa Região não quer se estabelecer, mas funciona como Região Intermediária. A linha continua seu curso descendente alcançando a sétima do Acorde Vagante C\#7(alt), analisado como IV7 na SD e V7 na $M$, repousando na terça do C7M. Assim, a textura homofônica com os blocos de acordes é substituída por uma voz que se direciona no sentido do discurso e promove, juntamente com a melodia, um contraponto a duas vozes. No c.17, a transformação do II grau foi aproveitada para criar uma linha cromática com as notas do baixo.

\section{Intervenções na forma de 23 de Junho de 1996:}

Para a Introdução (Ex.10), elaboramos um groove com os três primeiros acordes da peça: Am9, Am7/G e F7M.

A principal intervenção na forma para a lead sheet de realização se deu em função do recurso mostrado no Ex.7, a inserção de Acordes Vagantes em torno do F\#m no início da Frase 2. Na primeira exposição da Tema, vamos apenas insinuar a mudança da t para a $\mathrm{D}$ com a progressão de acordes Eb7(\#11) - F\#m7(9) e as duas primeiras notas na Frase 2 (Lá - Sol\#) em semínimas pontuadas (Ex.11).

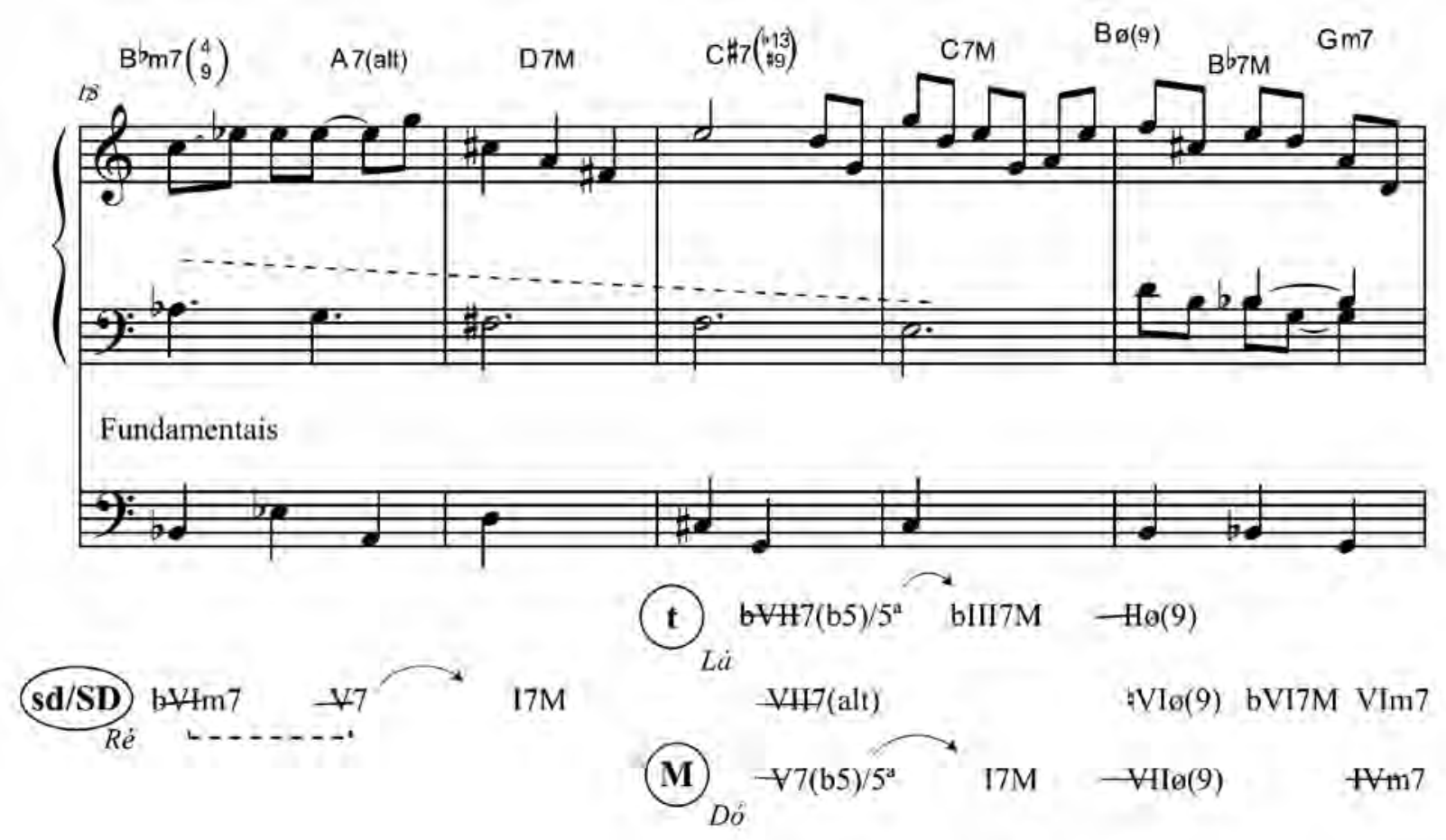

Ex.9 - Linhas contrapontísticas nos c.13-17 de 23 de junho de 1996 de Hermeto Pascoal.

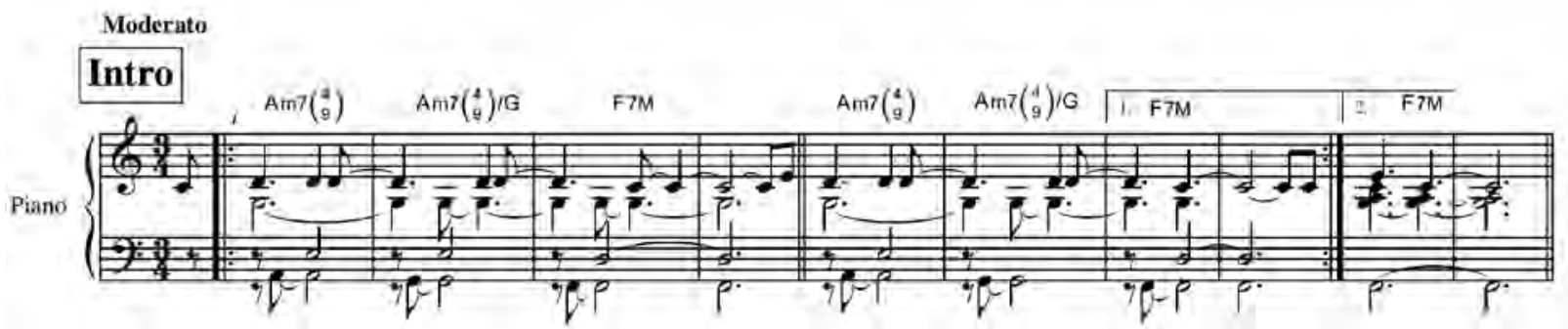

Ex.10 - Introdução com groove elaborado a partir dos primeiros acordes da música 23 de Junho de 1996 de Hermeto Pascoal. 

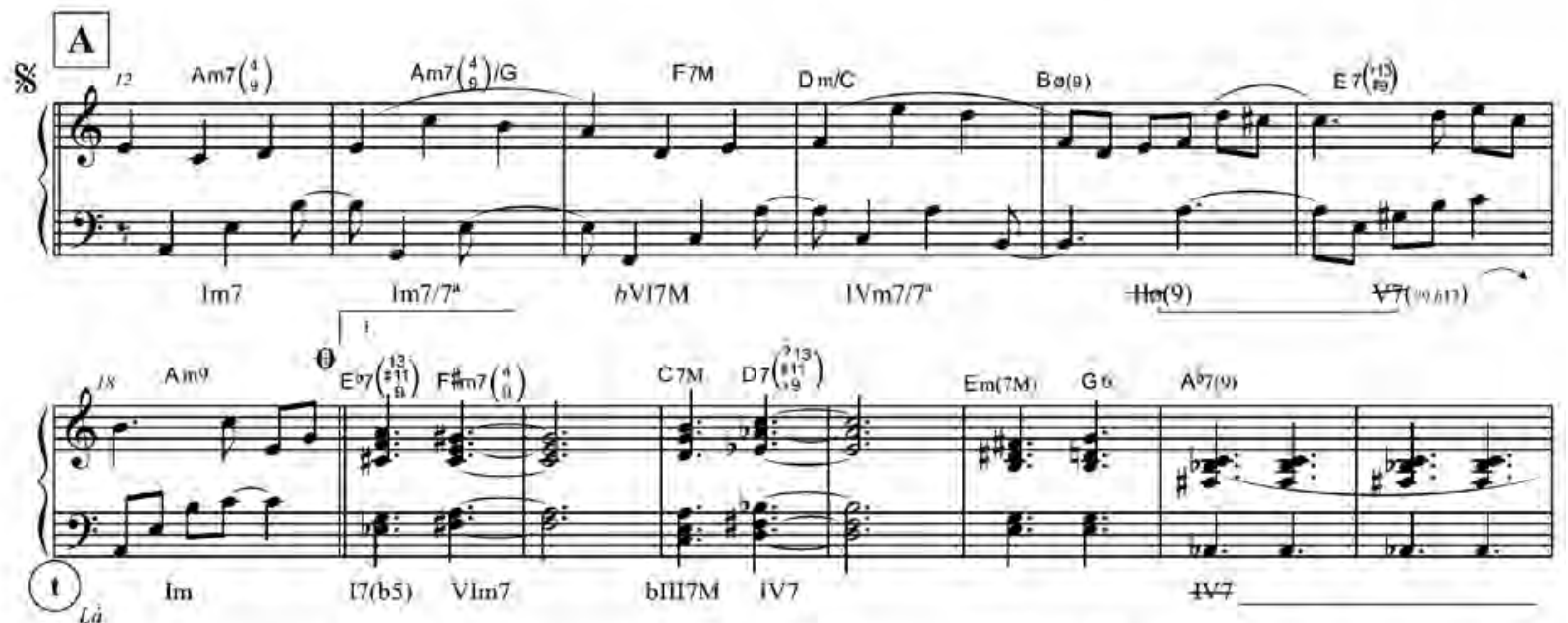

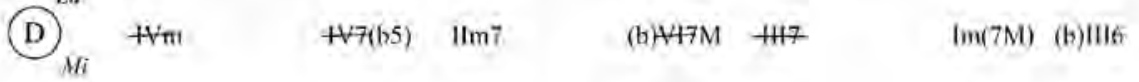

Ex.11 - Intervenção na forma da primeira exposição da Parte $A$ de 23 de Junho de 1996 de Hermeto Pascoal.

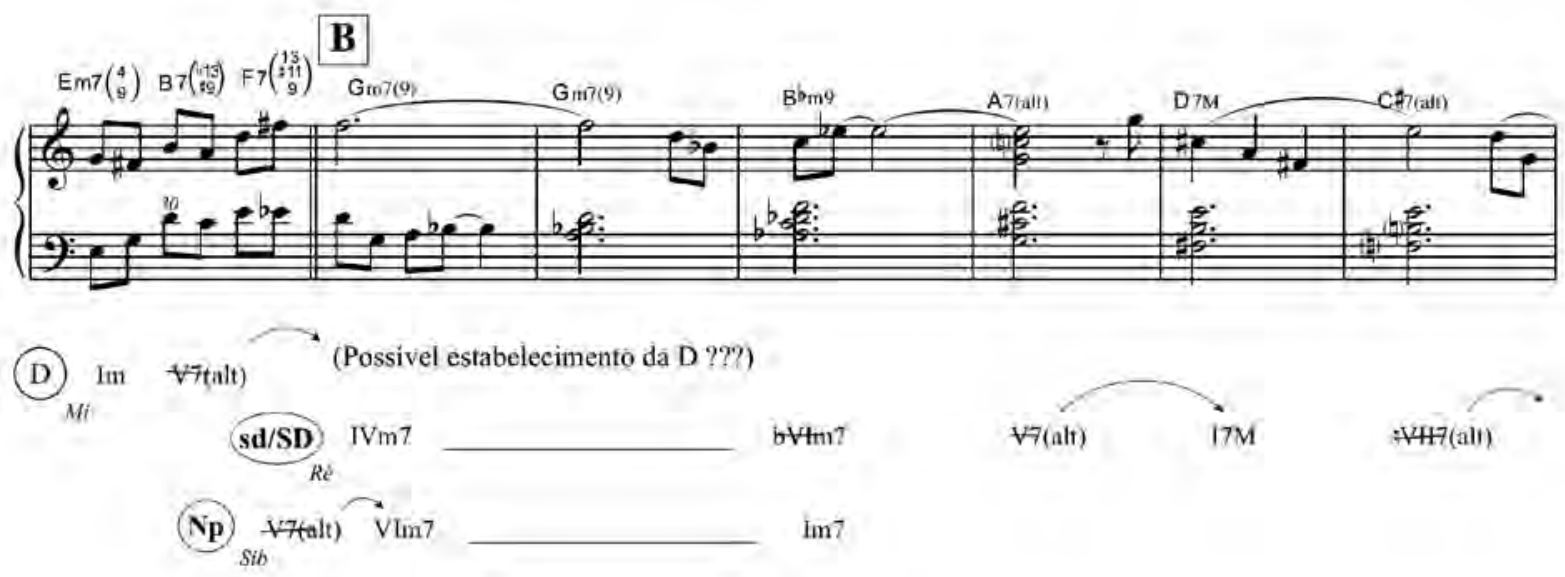

Ex.12 - Intervenção na forma com a chegada do acorde Gm7 em 23 de Junho de 1996 de Hermeto Pascoal.

Com isto, quebra-se a Forma-Sentença, mas por outro lado, coloca-se em evidência a Frase 1 e cria-se uma referência da Região D. 0 retorno à t é feito com o mesmo acorde usado na lead sheet original, o Ab7.

Com o estabelecimento da Região da $\mathrm{D}$, retorna-se à $\mathrm{t}$ com a Intro. Na segunda exposição do Tema, a Frase 2 é realizada com a harmonia elaborada no Ex.7 (veja acima). Porém, uma vez que a Região da $D$ foi anunciada como referência na exposição anterior, o movimento quase-diatônico ilustrado no segundo compasso do Ex.8 (veja acima) e sua continuação cromática a partir da intepretação de G257M/Eb como Acorde Vagante, permite que a chegada ao acorde $\mathrm{Gm} 7$ ganhe novo relevo.
Por isso, na lead sheet de realização, propomos alongar este acorde por mais um compasso (Ex.12), criando uma sensação de estabelecimento da Região sd/SD ou Np.

Com essas intervenções, a lead sheet foi dividida em duas partes. A ponte é um groove baseado na Intro, acrescentada de uma linha interna com a nota Fá\# sobre o acorde F7M. Sobre esse groove é realizado o solo de sax, que adquire assim um caráter modal. Após o solo de sax, segue o solo de piano estruturado sobre a harmonia do tema que transita principalmente entre as Regiões da t e da D. 0 ritmo usado é 6/4. Após o solo de piano, retornase à harmonia pedal da ponte, para o solo de contrabaixo, para então chegarmos à exposição final do tema. 


\section{4 - A canção instrumental 9 de Junho de 1997}

Esta peça apresenta uma estrutura mais complexa, em que predominam quatro acordes por compasso e uma melodia pouco convencional. 0 próprio Hermeto diz : "Essa música é bem linda e sofisticada, mas porém, muito cheia de energia. Viva ele [o som]" (PASCOAL, 2000a, p.374), o que já nos fornece uma pista sobre o caráter da música, embora não haja uma indicação de andamento. Vemos alguns sinais de articulação, como portamenti nos c.8, 9, 15 e 17; e acentos e ligaduras de expressão, no c.13, indicações de arpejo e ritmo harmônico dos acordes, cujas cifras apresentam normalmente a sétima e a inclusão de duas tensões. Seu esquema analítico completo é apresentado no Ex.54 ao final do artigo.

\section{1 - Variação Progressiva em 9 de Junho de 1997}

Motivos e Gestaltes:

Um Motivo pode ser um Intervalo, uma célula rítmica, um perfil melódico. 0 encadeamento destes motivos pode formar novas estruturas motívicas denominadas Gestaltes. No Ex.13a, b identificamos intervalos e células ritmicas como motivos.
No Ex.14a, b, c, d, e, f, identificamos os perfis melódicos. Os motivos $\boldsymbol{A}, \boldsymbol{B}, \boldsymbol{E}$ e $\boldsymbol{F}$ são movimentos de ligação melódica, como notas de passagem, escapadas, escapada por salto e resoluções indiretas (cambiatas). Os motivos $\boldsymbol{C}$ e $\boldsymbol{D}$ são compostos de dois saltos de intervalos diferentes em direções opostas.

0 Ex.15a, b, c, d, e, mostra as Gestaltes, que são estruturas motívicas mais complexas formadas pelo encadeamento dos motivos menores. As Gestaltes $\boldsymbol{A}, \boldsymbol{A 1}$ e $\boldsymbol{A 2}$ são caracterizadas principalmente pela combinação de perfis melódicos. A Gestalt B é fortemente marcada pela Figura rítmica $X$, sendo seu perfil melódico predominantemente uma variação do Motivo $D$. A Gestalt $C$, por sua vez, se caracteriza apenas pela Figura rítmica $Y$.

\section{Exposição:}

0 material temático principal da peça é exposto na Parte $A$, Frase 1 (c.1-4, Ex.16), e se constitui de duas partes contrastantes: a Frase $1 A$ e Frase $1 B$. No c. 1 encontramse dois importantes motivos de intervalos: o Motivo a 1 (6a $\mathrm{M}$ asc) e o Motivo b1 (2am asc). Três perfis melódicos são definidos neste compasso: Motivo $\boldsymbol{A}$ (célula de 3 notas em grau conjunto com uma nota de passagem),

\section{Motivos de intervalos}

a)

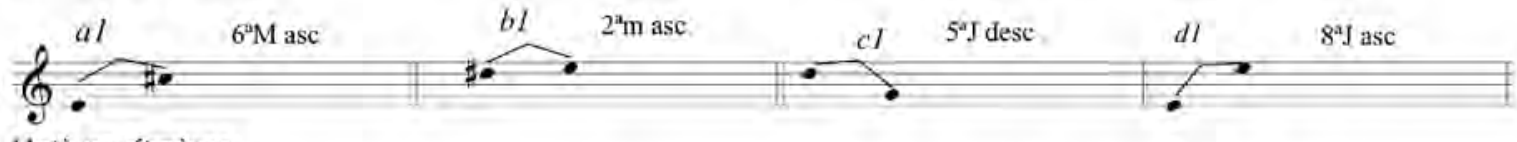
Motivos rítmicos

b)
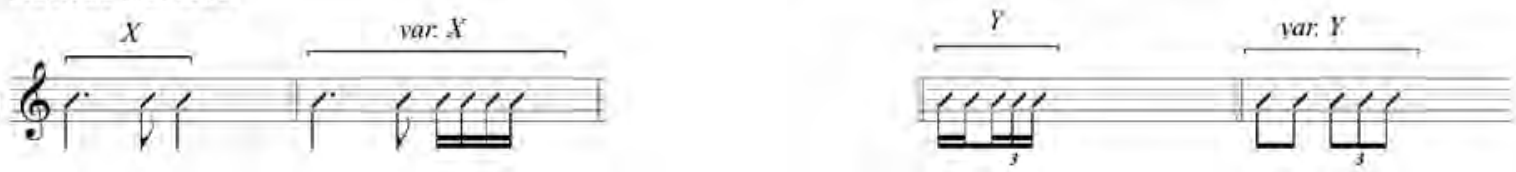

Ex.13 a, b - Motivos (intervalos e ritmos) em 9 de Junho de 1997 de Hermeto Pascoal.

\section{Perfis melódicos}

[gc] e [np]

a)

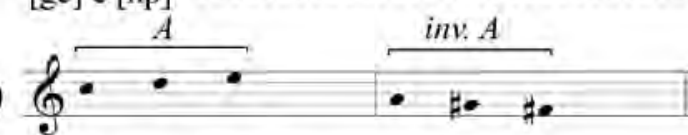

[e]

b)

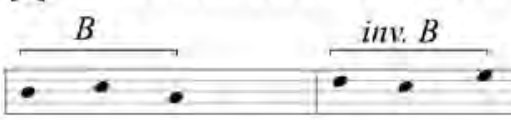

c)

$\left[8^{\mathrm{a}}+5^{\mathrm{a}}\right.$ ou $4^{\mathrm{a}} \mathrm{J}$ alternado $]-$

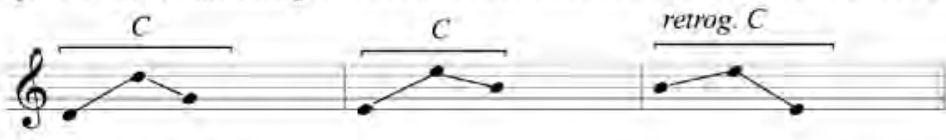

$\left[3^{a}+5^{a}\right.$ ou $6^{a}$ ou $7^{a}$ altemado $]$

d)

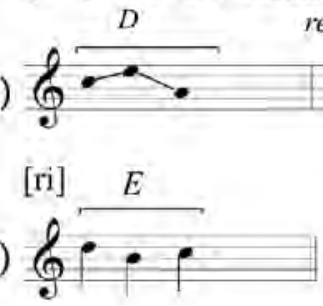

Legenda:

[gc] - grau conjunto [np] - nota de passagem

[e] - escapada

[es] - escapada por salto

[ri] - resolução indireta (cambiata)

Ex.14a,b,c,d,e,f - Perfis melódicos dos Motivos em 9 de Junho de 1997 de Hermeto Pascoal. 


\section{Gestalts}

Gestalt A

a)

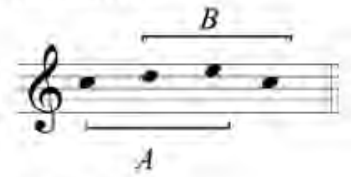

Gestalt Al

b)

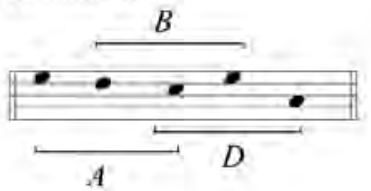

c)

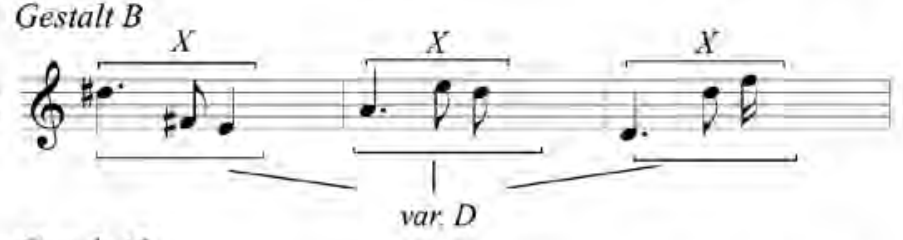

Gestalt A2 $D^{\prime}$

d)

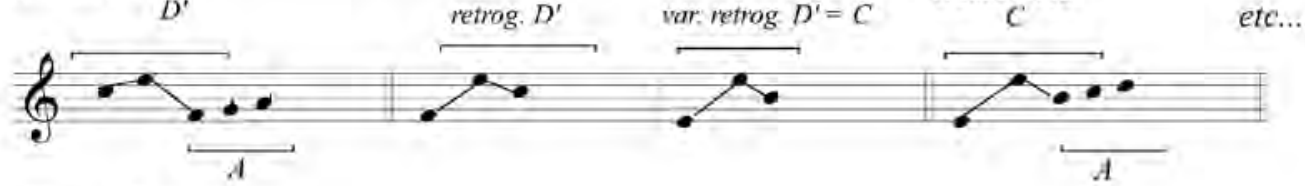

Gestalt C

e)

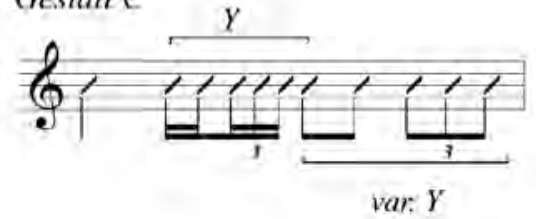

etc...

Ex.15a,b,c,d,e - Gestaltes com perfis melódicos dos Motivos em 9 de Junho de 1997 de Hermeto Pascoal.

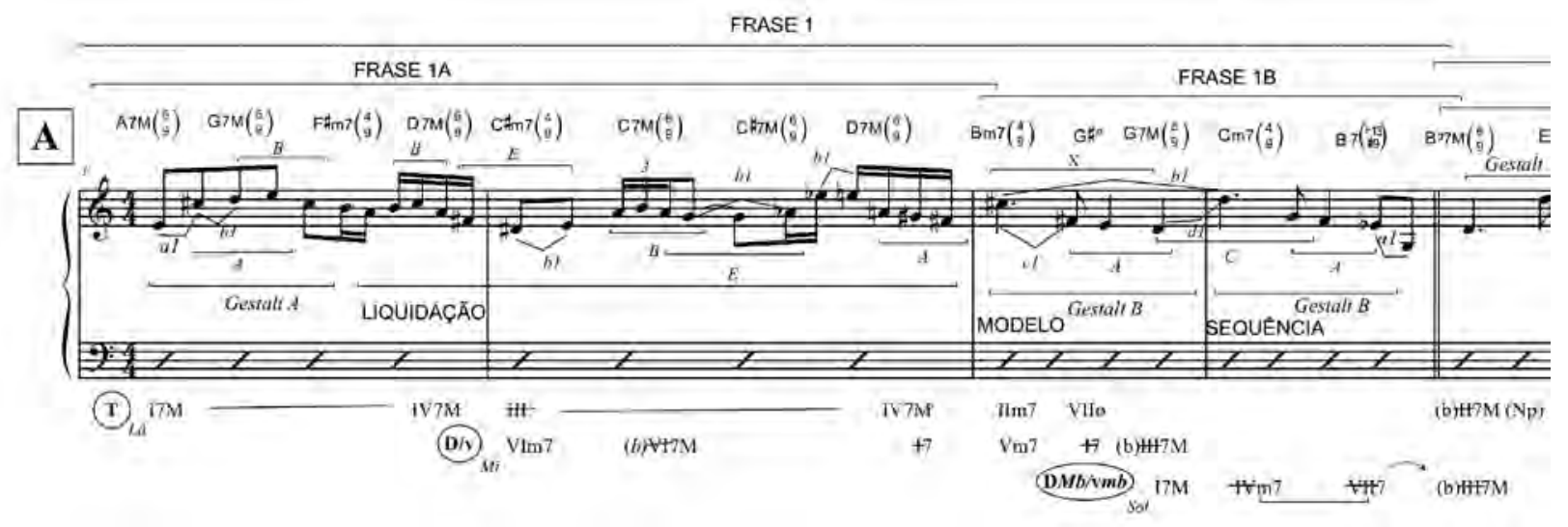

Ex.16 - Parte $A_{1}$ c.1-4 de 9 de Junho de 1997 de Hermeto Pascoal.

- Motivo B (célula de 3 notas com uma escapada) e o Motivo $E$ (célula de 3 notas formando uma resolução indireta). 0 encadeamento destes motivos gera a forma-

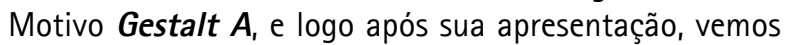
0 início de seu processo de liquidação que se estende até o c.2, delimitando assim a Frase 1A. A segunda parte, Frase $1 B$, consiste do alargamento do Motivo b1, e da inserção do Motivo $A$, formando com este encadeamento a forma-motivo Gestalt $B$. Nesta nova formação consolida-se a Figura rítmica $\boldsymbol{X}_{\boldsymbol{1}}$ que diminui o ritmo da evolução do discurso, tornando ambígua sua possível função consequente na Frase 1. A Gestalt B é usada com modelo e repetida em sequência no c.4. Do ponto de vista da harmonia, a Frase 1 é estruturada na T (Lá maior) passando pela região intermediária $\mathrm{D} / \mathrm{v}$, em direção a $\mathrm{DMb} / \mathrm{vmb}$ (Sol maior/menor). A liquidação da Gestalt $\boldsymbol{A}$ é estruturada sobre três transformações do III grau da T ou, como mostra a análise, sobre o VI da D/v, produzindo uma Harmonia Vagante.

Os c.5-7 parecem uma variação da Frase 1.0 inicio do c.5 apresenta uma variação da Gestalt B seguida de uma nova 
cadeia (Gestalt A1) formada por variações dos motivos $\boldsymbol{A}$ e $\boldsymbol{B}$, presentes na Gestalt $\boldsymbol{A}$ (Ex.17). 0 novo Motivo $\boldsymbol{D}\left(3^{\mathrm{a}} \mathrm{M}\right.$ asc. $+5^{\mathrm{a}}$ desc.) é produto da conexão $\boldsymbol{A}-\boldsymbol{B}-\boldsymbol{A}$. 0 c.6 é ritmicamente idêntico ao compasso precedente, mas produz uma nova combinação do Motivo $A$ com Motivo D' (uma variação do Motivo $D$ ) que se estabelece como a Gestalt $\boldsymbol{A 2}$. Finalmente, a frase se conclui com uma variação da Gestalt $B$ com um retorno a região da $t$ através de cadencia napolitana. Nesta variação mantémse o componente rítmico da Figura $\boldsymbol{X}$ (elemento mais marcantes desta Gestalt), enquanto o perfil melódico se forma com um "degrau" intercalado entre a primeira e a segunda parte do Motivo D', formando o Motivo $E$, que funciona como uma escapada por salto.

É notável a forma ambígua desta exposição do material temático. Por um lado, a estrutura sugere um periodo, sendo a Frase 10 antecedente e a variação da Frase 1, 0 consequente. Por outro lado, a variação da Frase 1 poderia ser mais um produto da variação de excertos, neste caso as Gestalts, da Frase 1 (forma aberta) do que uma repetição do antecedente do periodo (forma fechada). Esta estrutura aberta, que Schoenberg reconhece na Forma Sentença (Ex.18), é mantida progressivamente nas próximas partes de
9 de junho de 1997. Por isso demarcamos a Parte $B$ como um desenvolvimento e a Parte $\boldsymbol{C}$ como uma conclusão e Coda.

\section{Desenvolvimento das Gestaltes:}

No início da Parte $B$ (c.8-10) desenvolve-se a Gestalt A2, apresentada anteriormente, no c.6, como 0 encadeamento em semicolcheias dos motivos $\boldsymbol{D}^{\prime}$ e $\boldsymbol{A}$. Aqui ela é variada com o alargamento do Intervalo

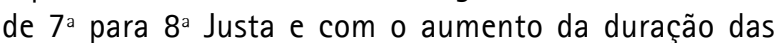
notas (de semicolcheias para colcheias). 0 Ex.19 mostra o mecanismo de variação do perfil melódico da Gestalt A2, do Motivo $D\left(3^{a}+5 \mathrm{~J}\right)$ para o Motivo $C\left(8^{\mathrm{a}}+5^{\mathrm{a}} / 4^{\mathrm{a}} \mathrm{J}\right)$. Este trecho (c.8-10) forma um padrão "modelo-sequência-liquidação". A harmonia ocorre na remota região (categoria 5) da SMvmb/smvmb (Mib maior/menor). A liquidação ocorre gradativamente a partir da sequência da Gestalt $\boldsymbol{A} 2$ passando pela região intermediária $\mathrm{D} / \mathrm{v}$, com diminuição das notas, $\mathrm{e}$ intensificando-se no c.10 em uma Harmonia Vagante com acordes expandidos da coleção de Lá octatônica, mas que conduzem de volta claramente à região da $\mathrm{T}$.

$\mathrm{Na}$ cadência que se estende nos c.11-12 surge um material secundário que mescla as Gestaltes $B, A 2$ e $A 1$.

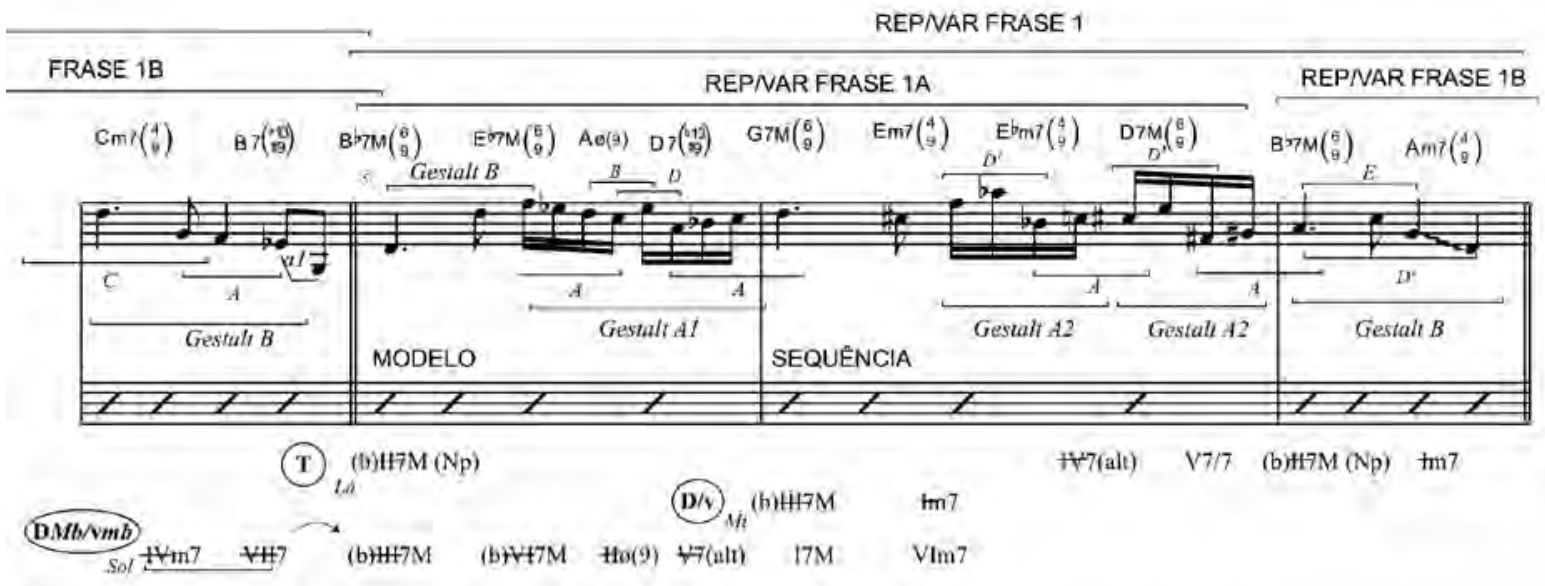

Ex.17 - Parte $A$, c.5-7 de 9 de Junho de 1997 de Hermeto Pascoal.

\begin{tabular}{|c|c|c|c|c|c|c|c|c|c|c|c|c|c|c|c|}
\hline \multicolumn{16}{|c|}{ Sentença } \\
\hline \multicolumn{8}{|c|}{$\begin{array}{c}\text { Exposiçáo } \\
\text { Parte A }\end{array}$} & \multicolumn{4}{|c|}{$\begin{array}{c}\text { Variaçăo de excertos (Desenvolvimento) } \\
\text { Parte B }\end{array}$} & \multicolumn{4}{|c|}{$\begin{array}{c}\text { Conciusâo } \\
\text { Parte Ce Coda }\end{array}$} \\
\hline \multicolumn{4}{|c|}{ Frase 1} & \multicolumn{4}{|c|}{$\begin{array}{l}\text { Repivar } \\
\text { Frase } 1\end{array}$} & \multicolumn{3}{|c|}{$\begin{array}{l}\text { Repp/var de } \\
\text { Gestalt A2 }\end{array}$} & $\begin{array}{l}\text { Repivar de } \\
\text { Gestalt B, } \\
\text { A2, A1 }\end{array}$ & \multicolumn{3}{|c|}{$\begin{array}{l}\text { Repivar de } \\
\text { Gestall B }\end{array}$} & \multirow{2}{*}{$\begin{array}{c}\begin{array}{c}\text { Rep/var de } \\
\text { Gestait A }\end{array} \\
\text { residuos }\end{array}$} \\
\hline \multirow{2}{*}{\multicolumn{2}{|c|}{$\begin{array}{l}\text { Frase 1A } \\
\text { Gestalt A }\end{array}$}} & \multirow{2}{*}{\multicolumn{2}{|c|}{$\begin{array}{l}\text { Frase } 18 \\
\text { Géstalt B }\end{array}$}} & \multicolumn{3}{|c|}{ Frase 1A' } & $\begin{array}{l}\text { Frase } \\
18\end{array}$ & \multirow{2}{*}{\multicolumn{2}{|c|}{ Gestalt A2 }} & \multirow{3}{*}{$\begin{array}{l}\text { Gestalt C } \\
\text { Liquidaçăo }\end{array}$} & \multirow{3}{*}{$\begin{array}{c}\begin{array}{c}\text { residuos } \\
\text { da Frase } 1\end{array} \\
\text { cadencia }\end{array}$} & \multirow{2}{*}{\multicolumn{2}{|c|}{ Gestalt B }} & \multirow{3}{*}{ 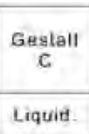 } & \\
\hline & & & & $\begin{array}{l}\text { Gestait } \\
B+A 1\end{array}$ & $\begin{array}{l}\text { Ges } \\
B+\end{array}$ & & $\begin{array}{c}\text { Gestalt } \\
B\end{array}$ & & & & & & & & \multirow{2}{*}{$\begin{array}{c}\begin{array}{c}\text { residuos } \\
\text { da Gestalt A }\end{array} \\
\text { sucessăo }\end{array}$} \\
\hline Gest. & Liquid & $\begin{array}{c}\text { Model } \\
0\end{array}$ & $\begin{array}{c}\text { Seque } \\
\text { ncia }\end{array}$ & Modelo & Segu & incia & cad $N p$ & $\begin{array}{c}\text { Mod } \\
\text { elo }\end{array}$ & Sequ. & & & Modelo & Seq. & & \\
\hline \multicolumn{4}{|c|}{ c.1.4 } & \multicolumn{4}{|c|}{ c. $5-7$} & \multicolumn{3}{|c|}{$0.8-10$} & $c .11-12$ & \multicolumn{3}{|c|}{$c .13 \cdot 15$} & c. $16 \cdot 18$ \\
\hline $\mathrm{T}$ & {$[\mathrm{D} / \mathrm{v}]$} & {$[\mathrm{D} / \mathrm{y}]$} & $\underset{m b}{\mathrm{D} m b / v}$ & $\begin{array}{l}\mathrm{D} m b / v m \\
b\end{array}$ & {$[D / v]$} & $\mathrm{T}$ & $\mathrm{T}$ & $\begin{array}{l}\text { SMDmb } \\
\text { IsmQmb }\end{array}$ & {$[\mathrm{D} / \mathrm{v}]$. } & $\begin{array}{l}{ }^{\top} \\
\text { (ac. vag.) }\end{array}$ & $\mathrm{T}$ & $\begin{array}{l}\text { T- } \\
\text { [SMSM } \\
\text { ismsm] }\end{array}$ & $\begin{array}{l}\text { ISMvm } \\
\text { b/smv } \\
\text { mb]- } \\
{[\mathrm{M}]}\end{array}$ & {$[M] \cdot \tau$} & 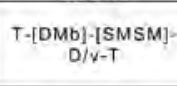 \\
\hline
\end{tabular}

Ex.18 - Estrutura das partes na Forma Sentença em 9 de Junho de 1997 de Hermeto Pascoal. 


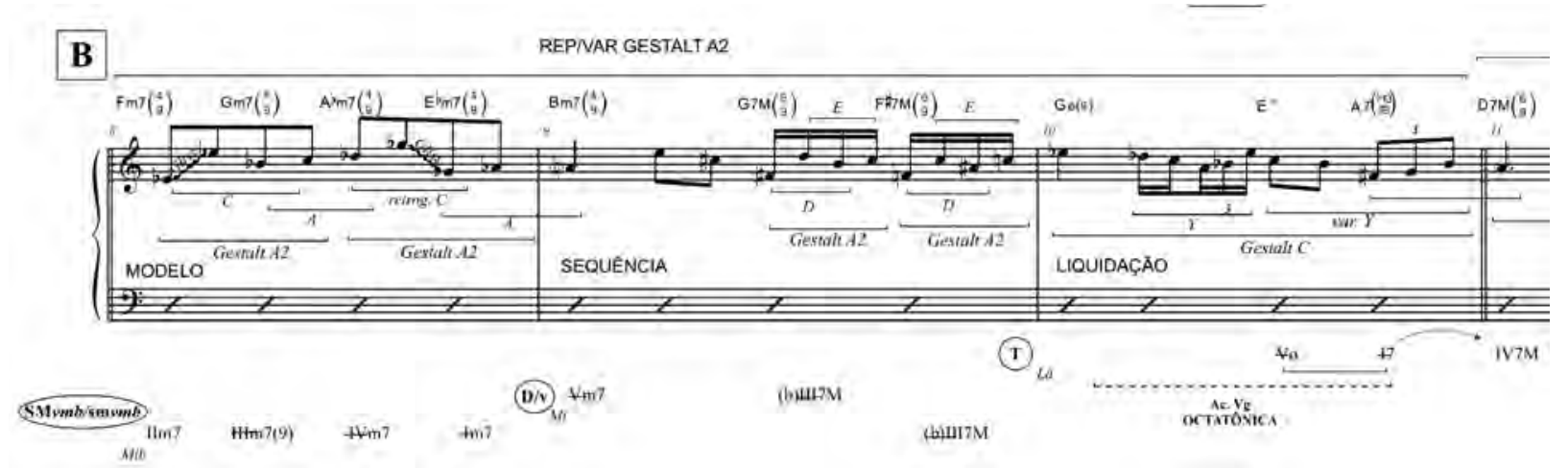

Ex.19 - Parte B, c.8-10 de 9 de Junho de 1997 de Hermeto Pascoal.

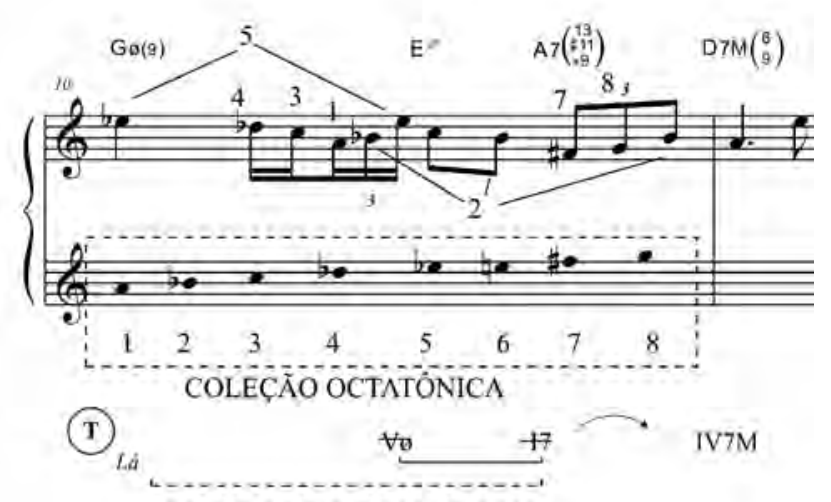

Ex.20 - Identificação da coleção octatônica no c.10 em 9 de Junho de 1997 de Hermeto Pascoal.

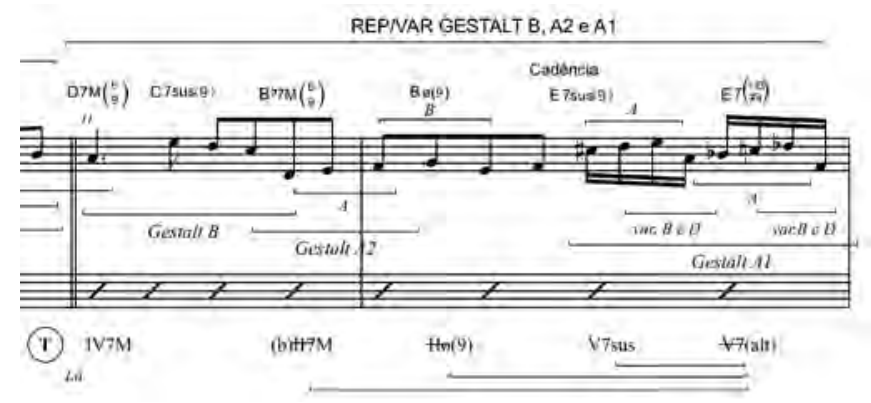

Ex.21 - Parte B, c.11-12 de 9 de Junho de 1997 de Hermeto Pascoal.

0 Acorde Vagante $\mathrm{A} 7$ relacionado à escala octatônica passa a corresponder aos acordes C7 - Eb7 e F\#7. 0 acorde Gø no primeiro tempo do compasso é o Il grau cadencial do correspondente $\mathrm{C} 7$, enquanto $\mathrm{E} \emptyset$, no terceiro tempo, é o II grau cadencial do A7. 0 Ex.20 associa as notas da melodia (pentagrama superior) com as notas da coleção octatônica (pentagrama inferior) numeradas de 1 a 8.

Essa harmonia coopera com o retorno à região da $\mathrm{T}$ na Parte $\boldsymbol{B}$ (Ex.21) iniciando uma longa cadência que passa pelo IV7M, que depois prolonga do II grau através de uma transformação da função napolitana seguida de uma derivação da menor melódica; e finalmente com o Prolongamento do V7, também por duas transformações.

\section{Conclusão da canção e Coda:}

A estrutura da Parte $\boldsymbol{C}$ (Ex.23) segue o mesmo padrão "modelo-sequência-liquidação", desenvolvendo desta vez a Gestalt $B$ nos c.13-15. 0 modelo é estruturado na região da $T$, mas é possível também compreender a harmonia da sequência tanto (1) como um desvio à $\mathrm{Mb}$ (Dó maior) quanto (2) uma influência da última remota região (Eb maior/menor) em estruturas enarmonizadas, invertidas e disfarçadas por permutabilidade maiorl 
menor. No primeiro caso, o acorde A\#m7(9), c.13, é enarmonizado como Bbm7(9), e considerado um Prolongamento do Db7M, acorde napolitano na Mb (Dó maior). 0 próximo acorde, um B7M Lídio, pode funcionar como G7(\#9,\#5)/B (Ex.22), isto é, $\forall 7 / 3$ a, como analisado no Ex.23, caracterizando uma cadencia napolitana, em direção ao C7M com o acorde Ab7M interpolado. Finalmente, no c.14 (Ex.23) através da Região Mb, iniciase uma cadência retornando à Região da T.

Por outro lado, pode-se notar uma influência da remota $\mathrm{SMvmb/smvmb} \mathrm{(Eb} \mathrm{maior/menor)} \mathrm{que} \mathrm{surgiria} \mathrm{pela}$ segunda vez no tema, mas desta vez vestida de SMSM/ smsm (Ré\# maior/menor). 0 terceiro acorde do c.13 C\#m7(9) introduz a região da D (Mi maior), e por uma permutabilidade maior menor é possivel visualizar a SM/ sm (Fa\# maior/menor) na sucessão C\#m7 - A\#m7. Com a reinterpretação das cifras dos acordes do c.14 (Db7M em D\#7/C\# e B7M em G\#m/B) chega-se finalmente à SMSM/ smsm (Ré\# maior/menor). Este seria o caminho lógico, mas Hermeto escreve todo o c.14 em bemóis cifrado os acordes Db7M e Ab7M intercalados pelo B7M, que neste contexto seria enarmonizado por Cb7M sugerindo a enarmonização de SMSM/smsm (Ré\# maior/menor) para SMvmb/smvmb (Eb maior/menor). 0 Ex.23 sumariza a análise da Parte $C$.

A Coda (c.16-18,) apresenta uma sucessão de acordes que representa as quatro regiões harmônicas da estrutura da peça (Ex.24).

0 acorde F\#7M (\#11) enarmonizado para Gb7M (\#11), representa o blll grau da smvmb (Mib menor). A mesma consideração deve ser feita para o acorde G7M ${ }^{(\# 11)}$. Este caráter formal de resumo do conteúdo apresentado na peça (Ex.25) e reforçado com linha melódica que apresenta em ordem inversa os motivos $B, b 1$ e a 1 da Gestalt $A$.

\section{2 - Harmonia em 9 de Junho de 1997: Regiões e Regiões Intermediárias}

0 primeiro movimento de regiões na Parte $A$ (Ex.26), é o deslocamento de ida e volta da T (Lá) para a DMb/vmb (Sol) passando pela região intermediária D/v. Trata-se de um movimento para região de categoria $2 a$, Indireta mas próxima. A relação entre essas regiões é derivada do $\mathbf{v}$ (Mi). A Região D/v (Mi) foi utilizada como intermediária

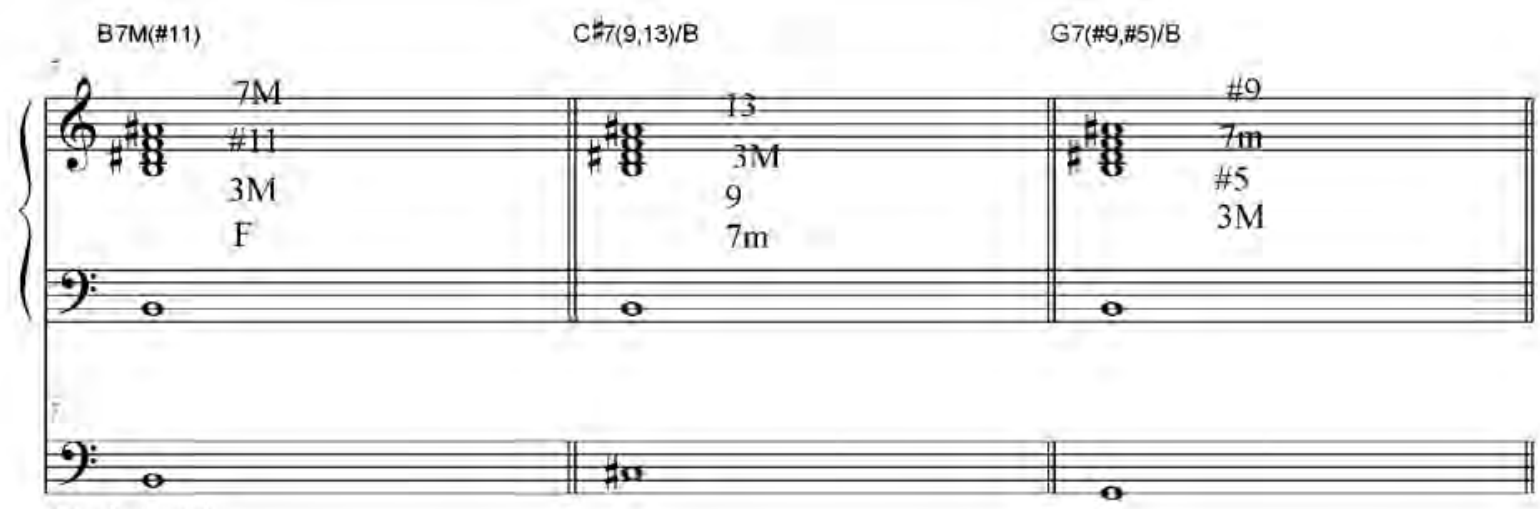

Fundamentais

Ex.22 - Reinterpretação da cifra B7M em 9 de Junho de 1997 de Hermeto Pascoal.

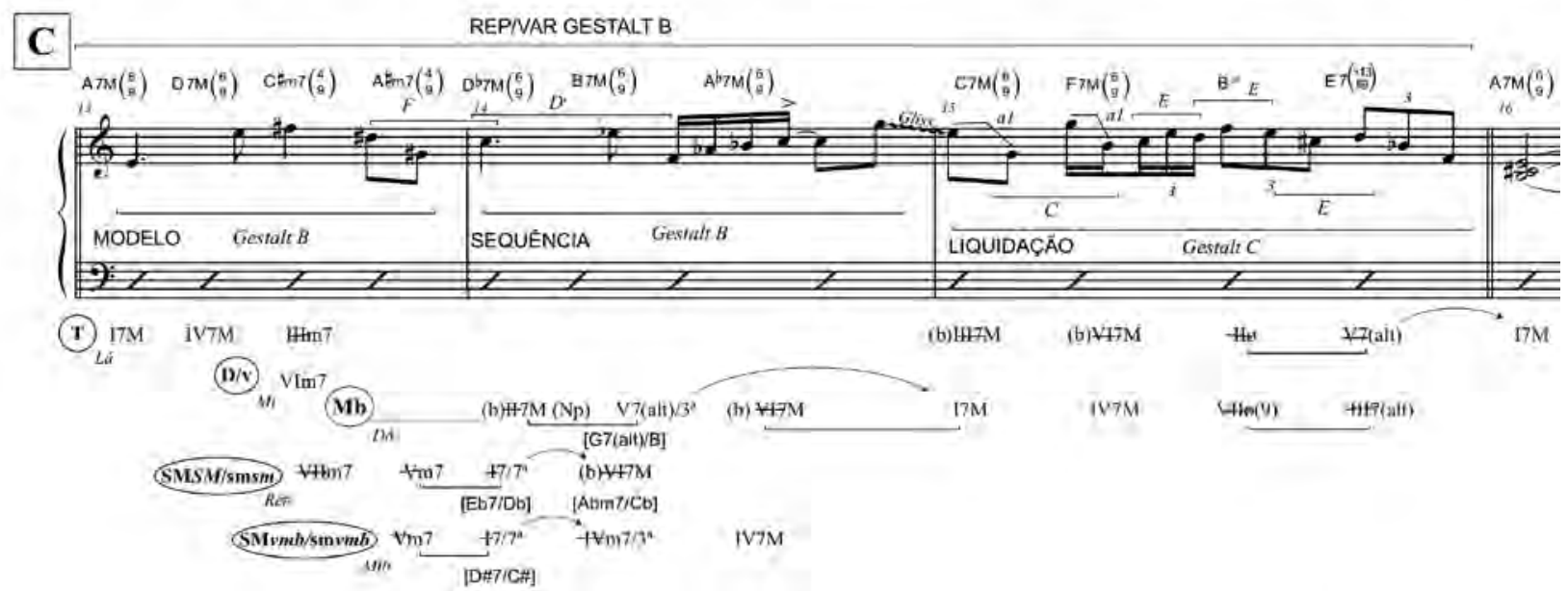

Ex.23 - Parte $C_{1}$ c.13-15 de 9 de Junho de 1997 de Hermeto Pascoal. 


\begin{tabular}{|c|c|}
\hline Acorde da CODA & Regiảo \\
\hline A7M & T \\
\hline G7M & DMb \\
\hline F\#7M $^{(\# 11)}-$ (Ebm6) & smvmb \\
\hline G7M $^{(\# 11)-(E m 6)}$ & $v$ \\
\hline
\end{tabular}

Ex.24- Regiões representadas pelos acordes na Coda de 9 de Junho de 1997 de Hermeto Pascoal.

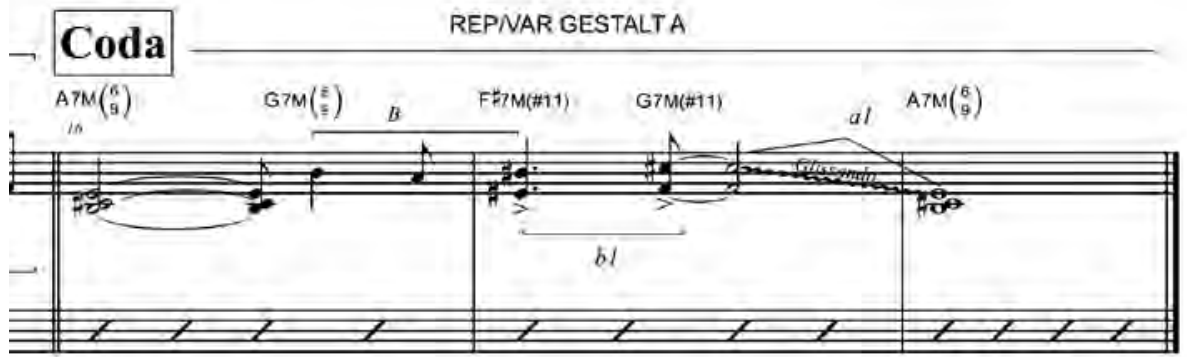
(T) $17 \mathrm{M}$
Fisus/7
HOFing
$+7$
I7M
(1D/) (b) $(\mathrm{tw}) \mathrm{M}$
(b) HFH

(1DMb/vmb $17 \mathrm{M}$

(SMvmb/smvmb) (b)HF/M

Ex.25 - Coda, c.16-18 de 9 de Junho de 1997 de Hermeto Pascoal.

PARTE A

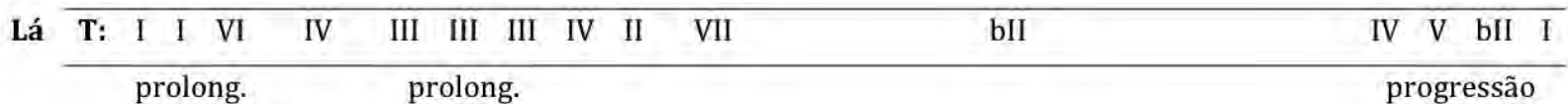

Mi

\begin{tabular}{lllllllllll}
\hline$[\mathbf{D} / \mathbf{v}]:$ & VI & VI & VI & 17 & V & I7 & bIII & bIII & Im \\
\hline \multicolumn{7}{c}{ prolong. } & & progress.
\end{tabular}

Sol

\begin{tabular}{ccccccccc}
\hline $\begin{array}{l}\text { DMb/ I } \\
\text { vmb: }\end{array}$ & IV & VII & bIII & bVI & II & V & I & VI \\
progressão
\end{tabular}

I $[\mathrm{V} / \mathrm{v}]$

VII/vii

$[\mathrm{V} / \mathrm{v}]$ $\mathbf{l} / \mathbf{i}$

Ex.26 - Percurso de Regiões na Parte $\boldsymbol{A}$ de 9 de Junho de 1997 de Hermeto Pascoal. 
com a utilização da relação direta da $\mathrm{D}$ com a $\mathrm{T}$,e da Permutabilidade Maior/Menor, que permite a conversão da $\mathrm{D}$ em $\mathbf{v}$, relativa da $\mathrm{DMb}(\mathrm{Sol})$.

T(Lá) - [D/v] (Mi) - DMb/vmb (Sol) - [D/v] (Mi) - T (Lá)

Na Parte $\boldsymbol{B}$ (Ex.27) os tempos fortes da linha melódica sugerem um arpejo de Ebm. A presença do acorde Gm7 pode acusar uma possível Região Maior/Menor sobre Mib:SMvmb/smvmb. Seria uma referência à importante Região da DMb/vmb (Sol) da Parte $A$, isto é, Mib maior como relativa de Sol menor. 0 salto da $\mathrm{T}$ à $\mathrm{SMvmb/}$ smvmb é justificado pela continuação que mostra a função cromática desta região em relação $D / v$ que segue e auxilia, novamente, o retorno à $\mathrm{T}$.

T (Lá) - [SMvmb] (Mib) - [D/v] (Mi) - T (Lá)

A Parte $C$ (Ex.28) esclarece as relações das duas outras partes, se os c.14-15 forem analisados na Região da Mb. Essa relação direta e próxima justificaria teoricamente a ocorrência das suas derivadas DMb/vmb, na Parte $A_{\text {, e }}$ SMDMb, na Parte $B$.

T (Lá) - [D/v] (Mi) - [SMSM](Ré\#)//[SMvmb](Mib) - Mb (Dó) - T (Lá)

\section{PARTE B}

Lá

Mi

Mib

\begin{tabular}{|c|c|c|c|c|c|}
\hline T: I & & & V 17 & IV bII II & V V \\
\hline & & ac. vag. & & progressão & \\
\hline & {$[\mathrm{D} / \mathrm{v}]: \mathrm{V}$} & bIII & & & \\
\hline
\end{tabular}

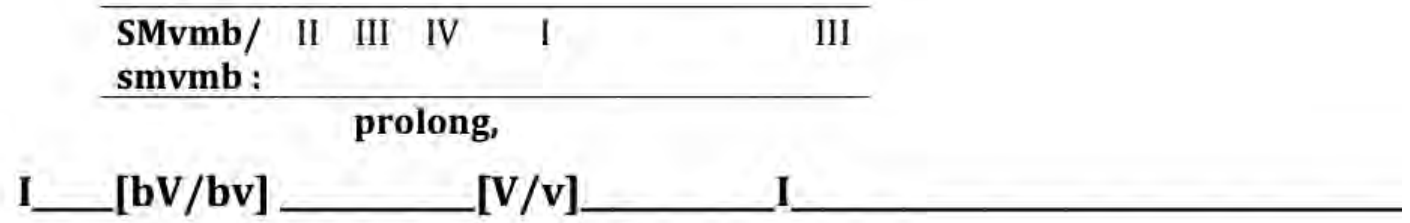

Ex.27 - Percurso de Regiões na Parte $\boldsymbol{B}$ de 9 de Junho de 1997 de Hermeto Pascoal.

PARTE C E CODA

Lá

Mi

Dó

Sol

Ré\#

Mib

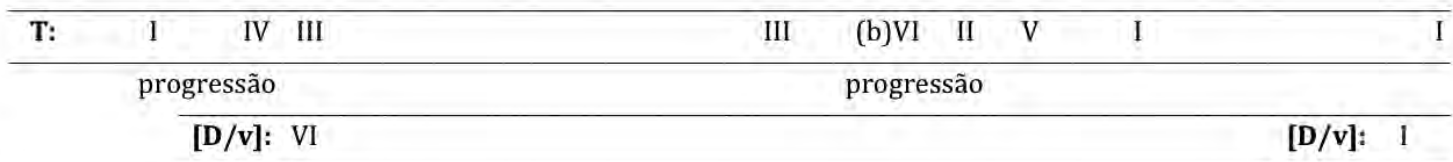

\begin{tabular}{cccccccc}
\hline Mb: & (b)II & V7 & (b)VI & I & IV & II & III \\
\hline \multicolumn{3}{c}{ progressão } & & & progressão
\end{tabular}

\begin{tabular}{lllllllll}
\hline $\begin{array}{l}\text { SMSM/ } \\
\text { smsm: }\end{array}$ & VI & V & I7 & bVI & & & I \\
\hline $\begin{array}{l}\text { SMvmb/ } \\
\text { smvmb : }\end{array}$ & V & I7 & IV & IV & & I \\
\hline
\end{tabular}

I $-\underset{[\mathrm{DIV} / \mathrm{v}]}{[\mathrm{iv}]}$ I

[bVII/vii]_[bv]_[v]__ I/i [bV/bv]

Ex.28 - Percurso de Regiões na Parte C e Coda de 9 de Junho de 1997 de Hermeto Pascoal. 
Na Coda, o movimento resume as regiões de destino e intermediárias percorridas:

$\mathrm{T}(\mathrm{Lá})-[\mathrm{DMb} / v m b](\mathrm{Sol})-[\mathrm{SMvmb}](\mathrm{Mib})-[\mathrm{D} / \mathrm{v}](\mathrm{Mi})$ - T (Lá)

\section{3 - Realização de 9 de Junho de 1997}

Criação de linhas cromáticas ou quase-diatônicas:

A análise do c. 1 nos permite criar uma linha cromática caracterizada pela transformação da sétima maior do acorde A7M em sétima menor, no segundo tempo, onde a cifragem G7M de Hermeto é analisada como 17 sus $/ 7^{\text {a }}$, isto é A7sus/G (Ex.29). A continuação da linha leva ao Fá\#.

No c.2, a nota Ré\#, sensivel da região $D / v$, é introduzida quase-diatônicamente através do Motivo $E$ (resolução indireta quasi-diatônica) para seguir para a nota tônica (Mi), formando o Motivo b1 (2am asc.). As transformações dos acordes deste compasso permitem um movimento de notas vizinhas em torno da terça maior (Sol\#) da região D/v. A linha criada faz o movimento de resolução indireta (Motivo E) cromática para o Sol\#. Em seguida, esta nota é aproveitada para funcionar como sensivel da $T$, ao seguir para a nota Lá, sétima do acorde $B m 7$, acorde neutro às duas regiões. A linha cromática reforça o caráter transitório da $\mathrm{D} / \mathrm{v}$ em direção à próxima região, $\mathrm{DMb}$ (Sol maior). Por isso, no c.3, assim que chegamos à nota Lá, pode-se iniciar uma nova imitação do Motivo b1 e assim produzir uma linha contrapontística partindo do Fá\# para alcançar o Sib (c.4), sétima do acorde $\mathrm{Cm} 7$, IVm7 da DMb/vmb (Sol maior/menor).

Ao executar esta linha interna com Motivo cromático b1, anuncia-se o movimento da voz principal Dó\# - Ré, ilustrado na linha A do Ex.30. 0 movimento completo se dirige para o Sib, conforme o traçado da linha B. 0 movimento de notas vizinhas sobre o Sib, ilustrado na linha C confirma o Sib como alvo e demonstra como as alterações do Acorde Vagante F7( ${ }^{\left({ }^{5}\right)}$, IV grau da DMb - que foi cifrado por Hermeto como B7(\#9,b13) - podem ser aproveitadas para gerar esse tipo de contorno melódico e executar a função harmônica.

\section{Intervenções na forma:}

Criadas as linhas para contraponto, vamos utilizar os dados da análise para interferir na forma do tema. 0 primeiro passo será determinar um groove para introduzir a música. Para isso vamos buscar elementos unificadores e sintéticos da peça. Destacamos a relação $\mathrm{T}$ - Mb, sobretudo pela presença de duas regiões indiretamente

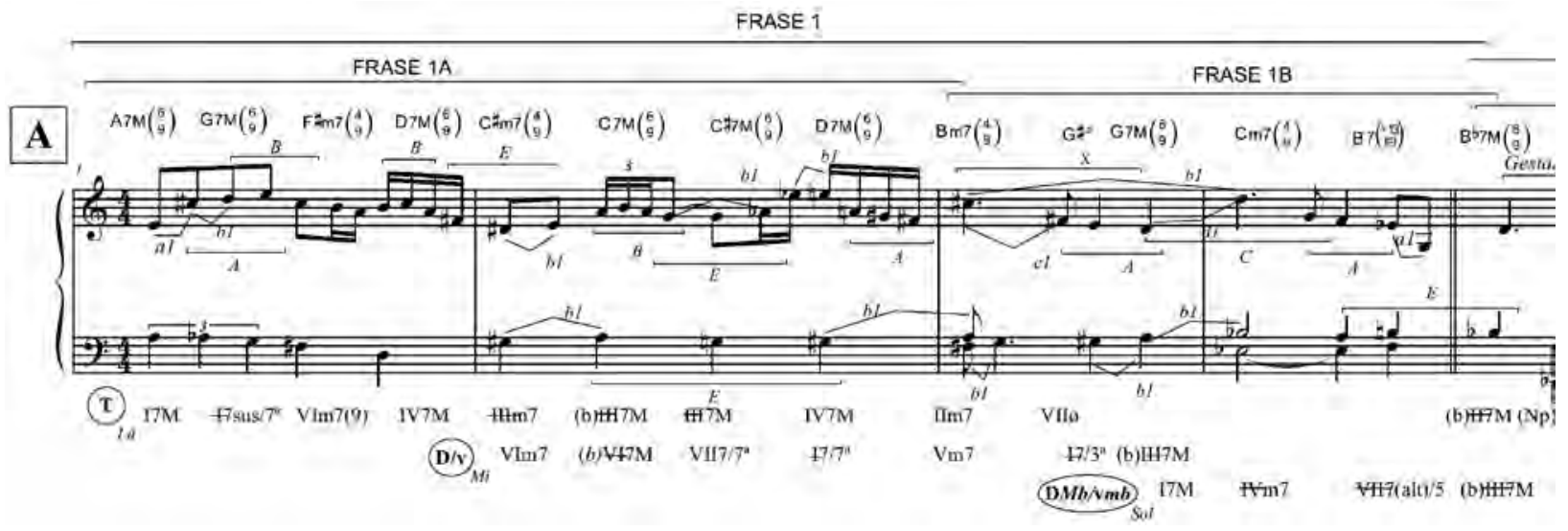

Ex.29 - Realização dos c.1-4 de 9 de Junho de 1997 de Hermeto Pascoal.

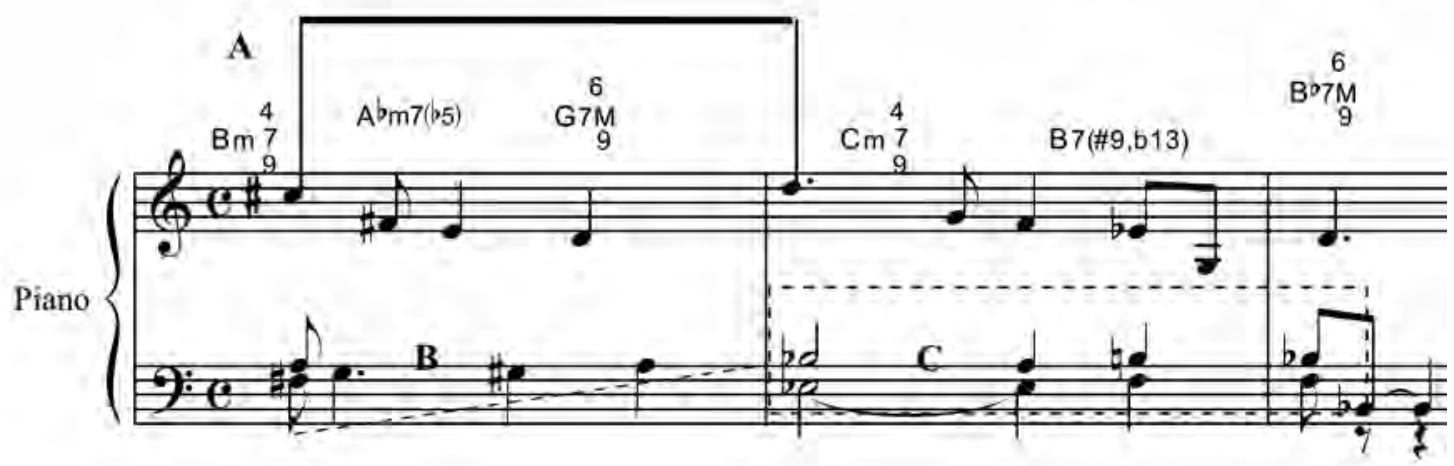

Ex.30 - Ilustração de linhas cromáticas A, B e C no c.3 de 9 de Junho de 1997 de Hermeto Pascoal. 
relacionadas com a Mb: a [DMb/vmb] (Sol) - [SMDMb] (Mib). Como se a tonalidade flutuasse em torno destas duas regiões ao longo da peça (Ex.31).

De fato, as regiões analisadas possuem relação com a Mb (Ex.32), mas esta região ocorre claramente em apenas nos c.14-15. Os acordes que sintetizam as regiões "satélites" desta peça são, portanto, A7M e C7M. Vamos usar esses dois acordes em uma Figura ritmica derivada do Motivo $Y$. Na montagem do groove daremos preferência a semínima pontuada. Isso nos levou a adotar o fell de duas semínimas pontuadas sobre um compasso de $3 / 4$, alternando os acordes com um voicing $\mathrm{A}(\mathrm{add} 2)$ e um $\mathrm{C}(\mathrm{add} 2)$ a cada compasso. No fim do ciclo de quatro compassos introduzimos uma díade de sétima maior, na região média-aguda com as notas $\mathrm{Mi}$ e Ré\#. Esse Intervalo anuncia com sonoridade distante a nota Ré\# do c.2 da lead sheet original, cuja função é de $6{ }^{\wedge}$ da Região da D/v.

Ao final das peças do Calendário do Som, Hermeto sempre escreve uma pequena mensagem, como uma anotação de um diário. Nesta peça ele diz: "Essa música é bem linda e sofisticada, mas porem, muito meiga e cheia de energia. viva ele (sic)" (PASCOAL, 2000, p.374). Conseguimos esse contraste entre uma sonoridade leve e uma enérgica mantendo o resultado que alcançamos na introdução com a fórmula de compasso em $3 / 4$. Por isso, esta será a primeira intervenção na apresentação da lead sheet de realização. Todos os exemplos daqui em diante serão apresentados nesta perspectiva e devem ser equiparados aos exemplos na versão original.

No. c.6, a melodia é executada em uma quartina sobre 0 3/4. 0 primeiro Intervalo de $6^{\mathrm{a}} \mathrm{M}$ asc. fica em segundo plano porque a nota $\mathrm{Mi}$ foi antecipada no último acorde $\mathrm{A}(\mathrm{addb2})$ da introdução, ficando a ênfase do tema inicial sobre o Motivo $\boldsymbol{A}$ (Dó-Ré-Mi). 0 segundo acorde é definitivamente cifrado como uma transformação do I grau da T, A7sus/G. Sobrepomos, portanto a linha de substituição cromática (Lá-Láb-Sol), e na nota Sol montamos o "acorde de apoio" (Sol-Si-Ré-Fá\#). A linha da clave de Fá do c.2 do Ex.29 (veja acima), mais acima, será incorporada aos voicings especiais invertidos, como demonstra o c.8-9 do Ex.33. A linha Sol\#-Lá (Motivo b1) fica no baixo dos primeiros dois acordes, e a continuação Lá-Sol-Sol\# (Motivo E), vai para a voz superior dos dois últimos acordes. Com esta interpretação valorizase o Motivo b1 alargando progressivamente o valor da segunda Figura do par de semínimas pontuadas da introdução (veja Ex.35 a,b abaixo).
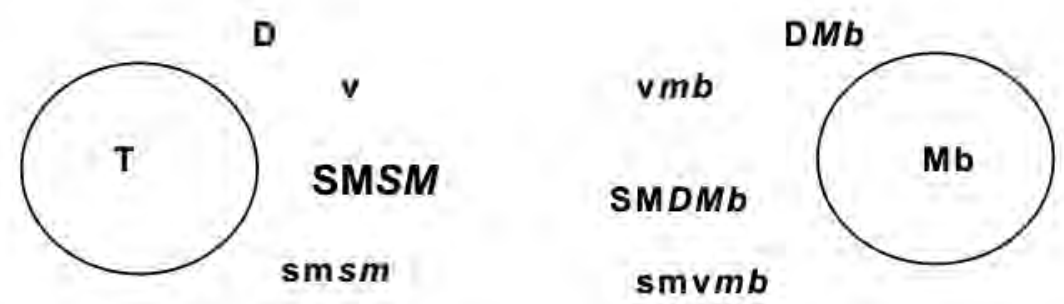

Ex.31 - Esquema de Flutuação da tonalidade em torno de Regiões polarizadas pela T e pela Mb em 9 de Junho de 1997 de Hermeto Pascoal.

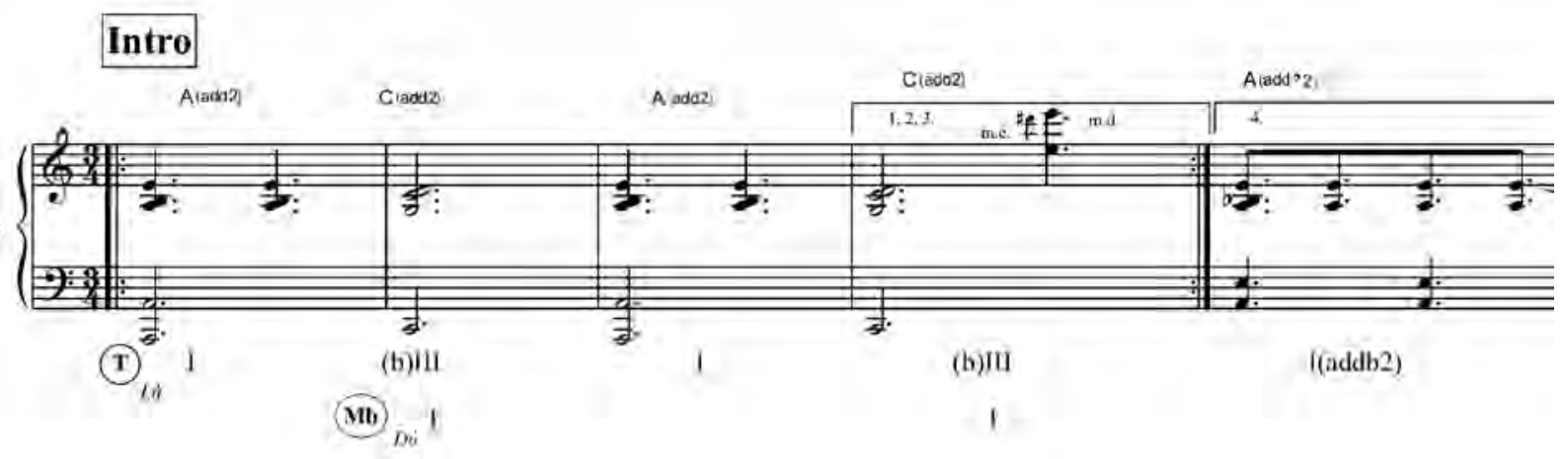

Ex.32 - Introdução com acordes representantes da T (Lá maior ) e Mb (Dó maior) em 9 de Junho de 1997 de Hermeto Pascoal. 


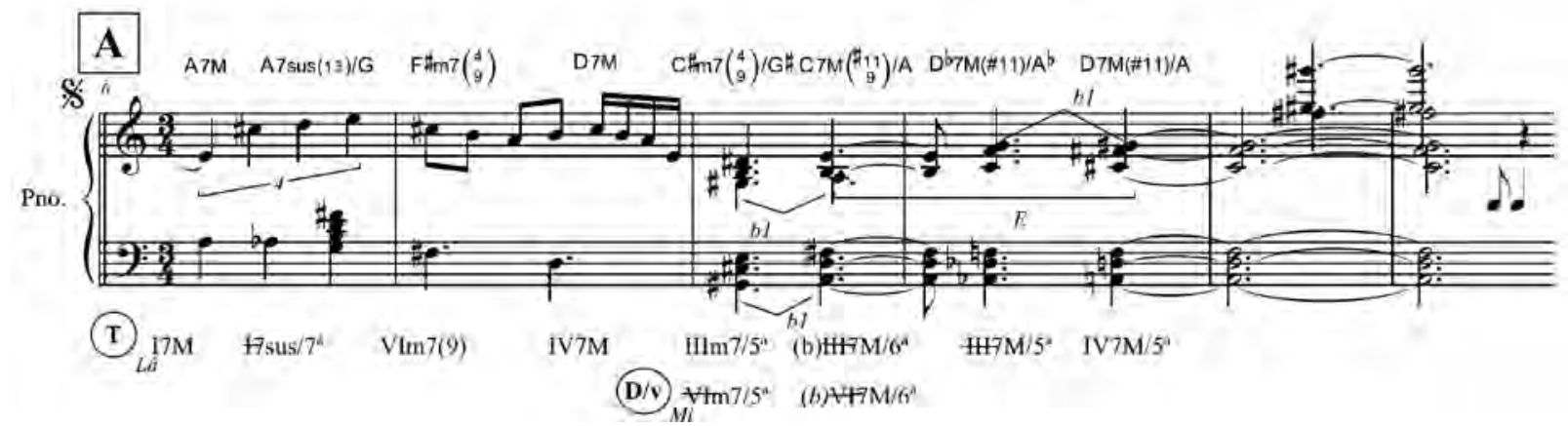

Ex.33 - Parte $A$, c.6-11 da lead sheet de realização 9 de Junho de 1997 de Hermeto Pascoal.

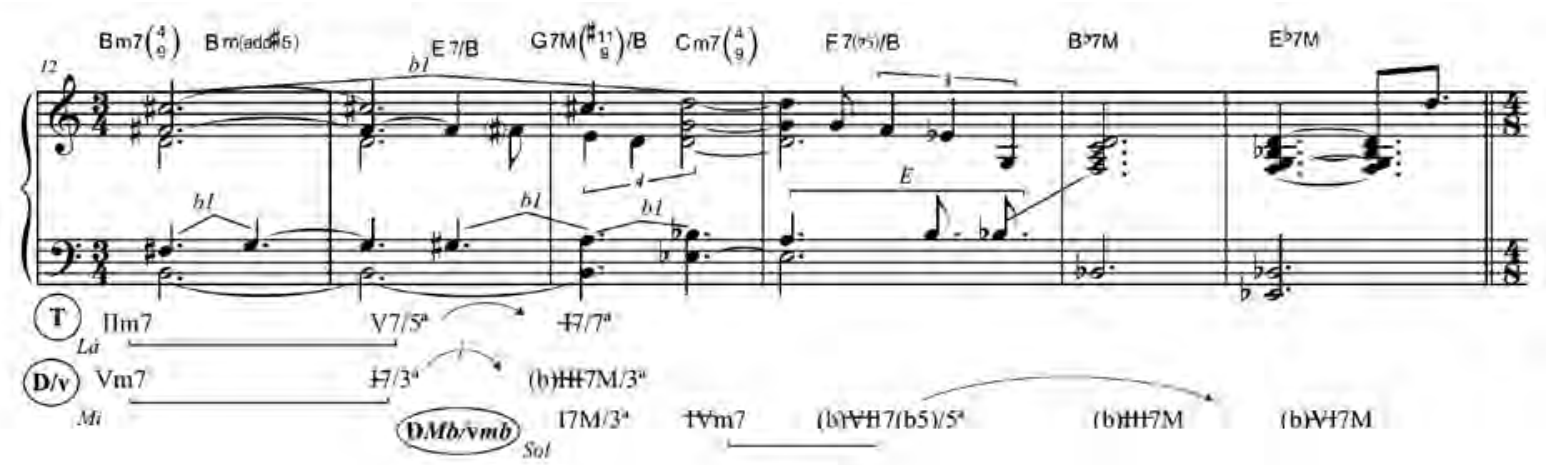

Ex.34 - Parte $A$, c.12-17 da lead sheet de realização 9 de Junho de 1997 de Hermeto Pascoal.

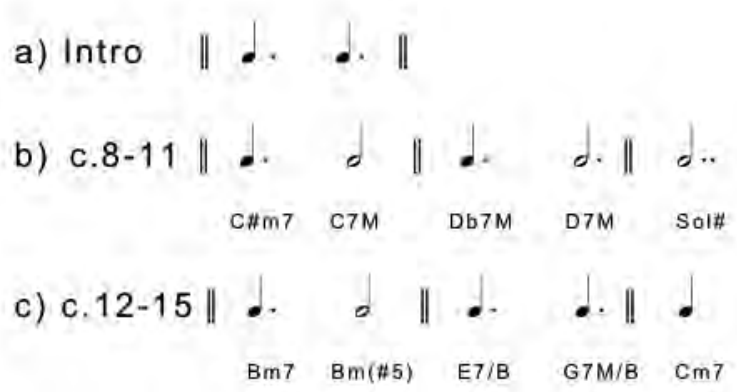

Ex.35 a,b,c - Variações do Motivo rítmico da introdução da lead sheet de realização de 9 de Junho de 1997 de Hermeto Pascoal.

Nos c.12-14 (Ex.34), a linha cromática $B$ desenvolvida no Ex.30 (veja acima), é executada em uma voz interna sob um baixo pedal em Si até o acorde $\mathrm{Cm} 7$. Esta linha cromática enfraquece a sensação centripeta sobre a $\mathrm{T}$ mesmo que seja possível analisar uma cadência II-V-I. Por outro lado, ela sugere a Permutabilidade maior/ menor da região intermediária $\mathrm{D} / \mathrm{v}(\mathrm{Mi})$ que permitirá a transição para a $\mathrm{DMb}$ (Sol) no c.14. 0 resultado é uma textura com a voz superior (Dó\#-Ré) - identificada na letra A do Ex.30 (veja acima), movendo-se junto com o baixo pedal enquanto a linha ascendente $B$ se contrapõe em movimento contrário com a melodia. Todo o trecho é um desenvolvimento do Motivo b1. No c.15 tem início a Permutabilidade maior/menor da região $\mathrm{DMb}$ para $\mathbf{v} \boldsymbol{m b}$ e o Motivo E(linha C do Ex.30 acima) para realizar o Acorde Vagante $\mathrm{F} 7 / \mathrm{Cb}$ cifrado originalmente como B7(\#9,b13).
Chamamos atenção para os elementos de unidade e contraste desta primeira parte da realização. A variação da Figura rítmica da introdução (Ex.35a) nos c.8-11 faz com que a segunda semínima pontuada de cada bloco seja alargada progressivamente (Ex.35b) enquanto a textura do trecho é homofônica com acordes de sonoridade densa até se dissolver em um cluster (Sol\# em oitava com e Fá\#) com duração de uma mínima duplamente pontuada para antes da pausa de semínima no último tempo do c.11 pra fechar o compasso de 3/4. 0 Ex.35a, b, c mostra que a Figura rítmica dos c.8-11 funciona como modelo em sequência variada nos c.12-15. Embora o Motivo b1 unifique toda a parte $A$, neste trecho (c.12-15) a textura é polifônica e Motivo rítmico é intensificado até retornar ao padrão da introdução. 
A Parte $B$ (Ex.36), que irá desenvolver a Gestalt $\boldsymbol{A} 2$, será escrita em $4 / 8$ nos c.18-22. Esta mudança reforça o aspecto contrastante citado no comentário de Hermeto. Neste trecho, a mera contraposição da melodia com um arpejo dos acordes cifrados proporciona uma sucessão de intervalos dissonantes, sobretudo, de $7^{\text {as }}$ resultando num um jogo de timbres nos pontos de encontro entre as duas

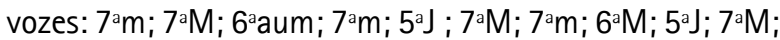
$7^{\mathrm{a}} \mathrm{m} ; 4^{\mathrm{a} J} ; 7^{\mathrm{a} M}$. Na cadência napolitana para a T (c.23-24), o compasso em $3 / 4$ pontua o fim da variação da Gestalt $A 1$ e funciona como ligação para a próxima variação.

Nos c.25-27 (Ex.37), em 4/8, utilizamos "acordes de apoio" para uma textura homofônica, e nos c. 28-39 retomamos o arpejo nota contra nota com a melodia. Logo na entrada do trecho de Acordes Vagantes da diminuta (c.30), a fórmula de compasso retorna para $3 / 4$ por apenas um compasso para voltar a $4 / 8$ do c.31 ao 37 (Ex.38).

Na realização da Parte $C$ (Ex.39) a condução das vozes indica que a harmonia transitou sobre as funções indicadas com a linha tracejada.

A seção de solos é aberta para o contrabaixo improvisar sobre os acordes do primeiro compasso da parte A (Ex.40), porém com pedal em Lá. Poucas harmonia em uma seção para improvisação é típico do que se conhece como improvisação modal no jargão jazzístico. 0 improvisador não

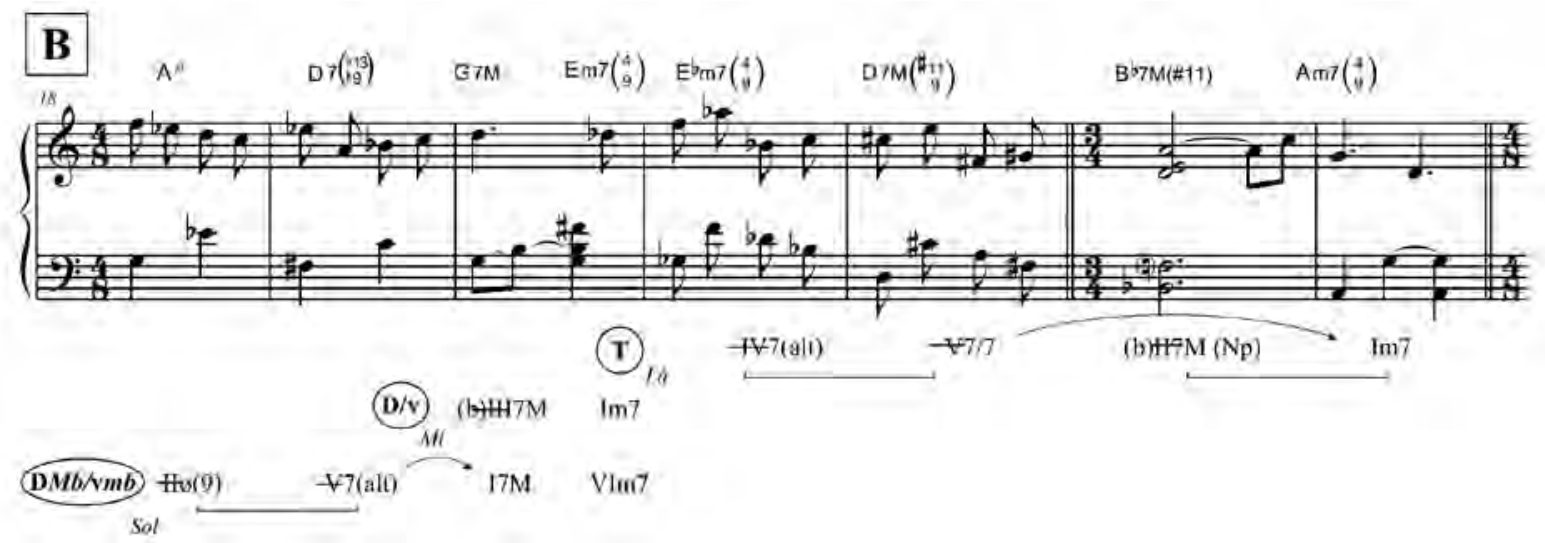

Ex.36 - Parte B, c.18-24 da lead sheet de realização 9 de Junho de 1997 de Hermeto Pascoal.

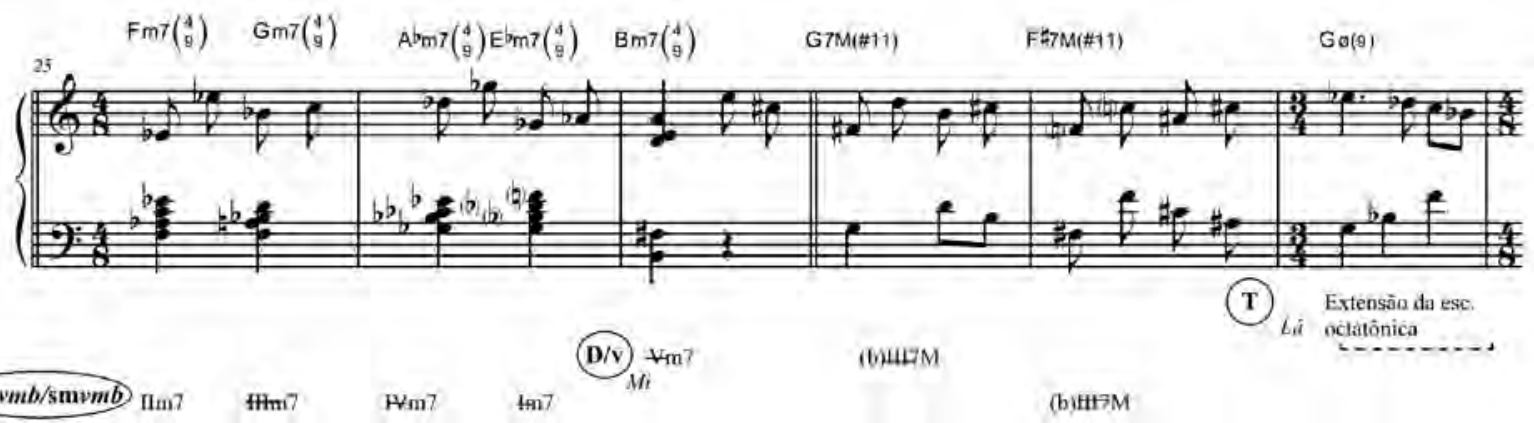

Ex.37 - Parte B, c.25-30 da lead sheet de realização 9 de Junho de 1997 de Hermeto Pascoal.

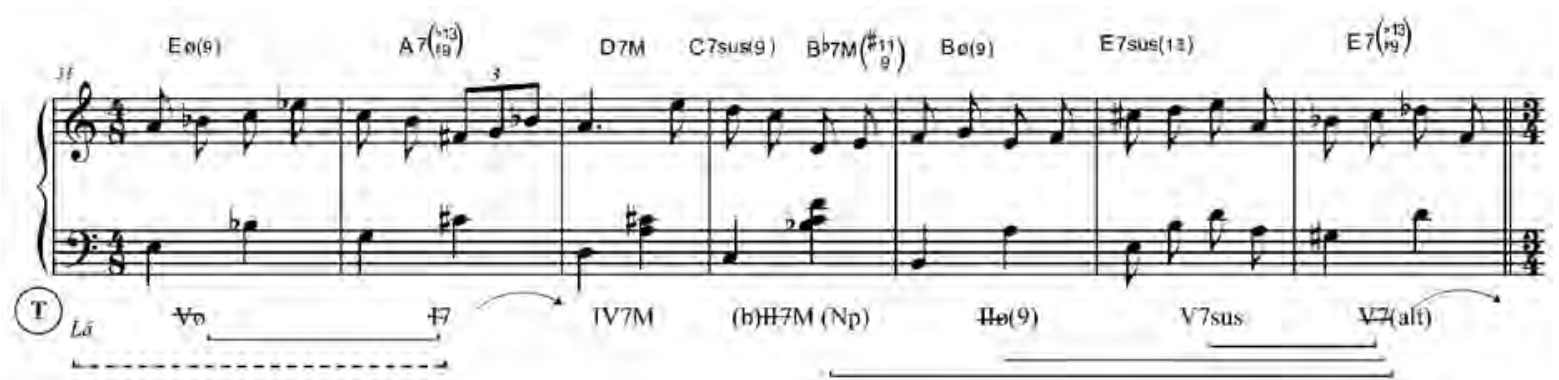

Ex.38 - Parte B, c.31-37 da lead sheet de realização 9 de Junho de 1997 de Hermeto Pascoal. 


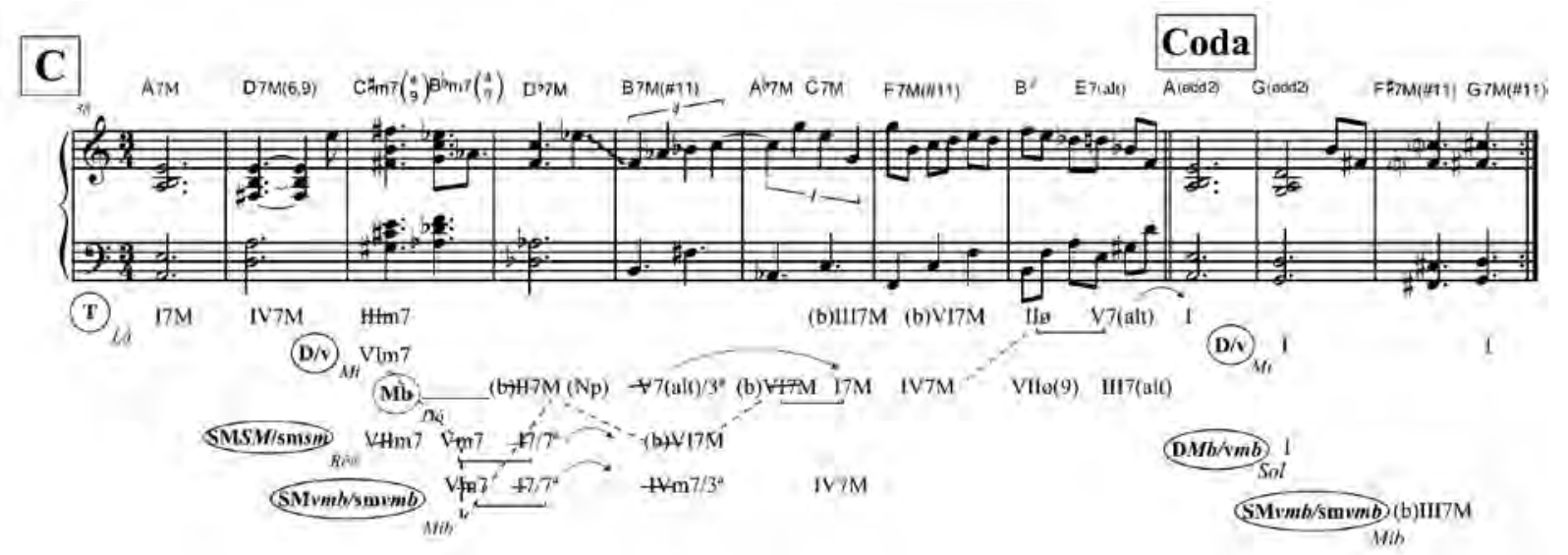

Ex.39 - Parte $C$ e Coda, c.38-48 da lead sheet de realização 9 de Junho de 1997 de Hermeto Pascoal.

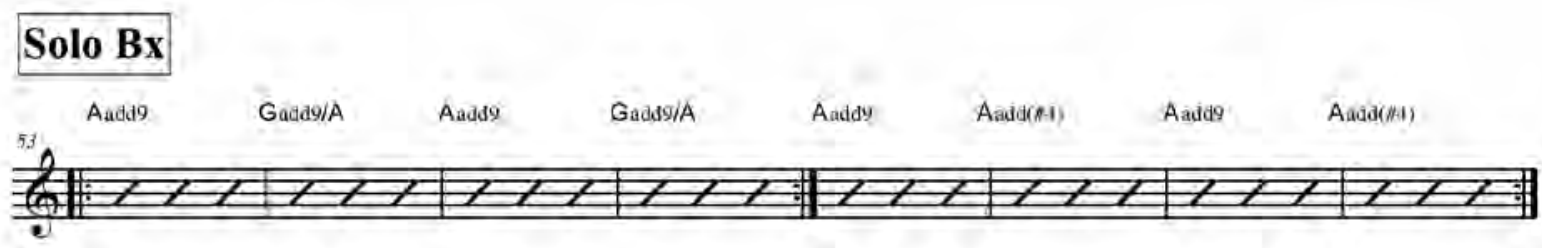

Ex.40 - Harmonia para o solo de contrabaixo na lead sheet de realização 9 de Junho de 1997 de Hermeto Pascoal.

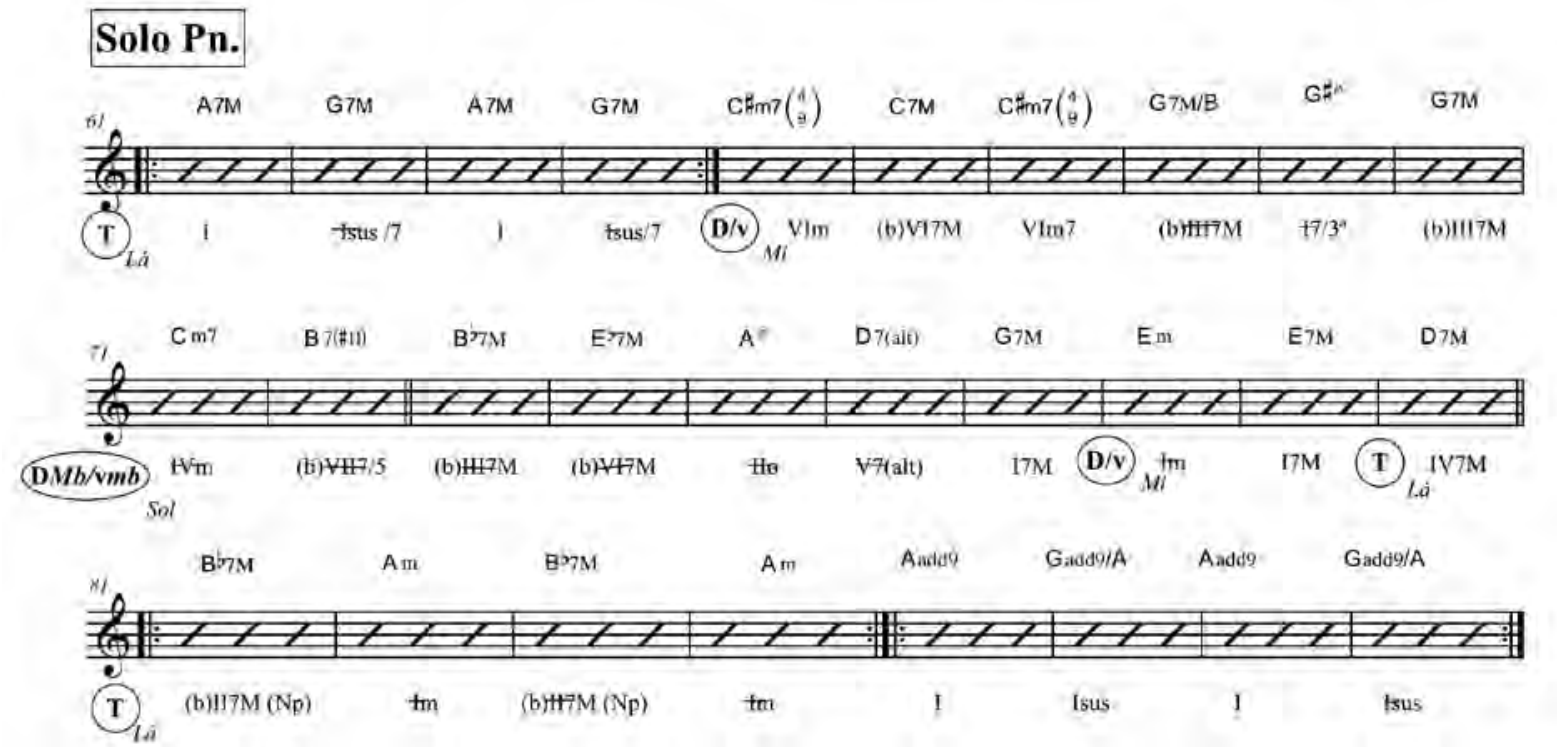

Ex.41 - Harmonia para o solo de piano na lead sheet de realização de 9 de Junho de 1997 de Hermeto Pascoal.

improvisa sobre os encadeamentos mas sobre a escala ou modo predominante nos poucos acordes envolvidos. Neste caso, A(add9) e G(add9)/A, usa-se escalas pentatônicas de Lá e Sol, ou o modo Mi Dórico (Mi-Fá\#-Sol-Lá-Si-Dó\#Ré). Porém, essas escolhas são muito particulares de cada improvisador, que pode fazer um solo mais ou menos outside. No segundo ciclo, sugere-se o acorde A(add\#4) para anunciar a nota Ré\# (presente no tema sobre 0 primeiro acorde C\#m7(9)). Esta parte, que pode ser bem livre na improvisação, sugere um pico de tensão no segundo bloco, inclusive em diálogo com a bateria.

Na parte de solo de piano (Ex.41), a harmonia retoma o frescor da sucessão $A($ add9) e G(add9)/A, mas após 4 ciclos ela percorre o trajeto do tema: T - D/v - DMb/ $v m b-D / v$ - T. A primeira parte na T se dá com a 
transformação do I grau sus com baixo na sétima. A segunda parte mostra o trecho na $D / v$ com as transformações por Permutabilidade maior-menor. Já na terceira parte, na $\mathrm{DMb} / \mathbf{v m b}$, prevalecem os acordes na $v \boldsymbol{m} \boldsymbol{b}$ mas a conclusão é o $17 \mathrm{M}$ da DMb, que possibilita a transição de volta para a D/v que, por sua vez, limita-se a apresentar suas duas configurações de tônica, Em e E7M. 0 último trecho, na T, apresenta o IV7M em um par de acordes do mesmo tipo com o da última região e segue com o contraste provido por uma cadência napolitana se dirigindo para a t. 0 retorno ao tema ocorre depois de um groove na $\mathrm{T}$ com a mesma harmonia utilizada no solo de contrabaixo. A seguir apresentamos os esquemas analíticos completos das duas canções instrumentais de Hermeto Pascoal analisadas sesse artigo: 26 de Junho de 1996 (Ex.42) e 9 de Junho de 1997 (Ex.43).

\section{6 - Considerações finais}

Admirada no Brasil e no exterior pela sua criatividade libertária e ecletismo, a música de Hermeto Pascoal ainda causa receio ou distanciamento em muitos que gostariam de entender a lógica de suas harmonias e estruturas formais, ou simplesmente, tocá-la. Para outros, não poucos, as conhecidas "loucuras" de sua figura mística, ideias e natureza indomável de sua personalidade se reflete no "caos" de sua música. Mas trata-se de um caos aparente. Mostramos aqui que, apesar de ser um autodidata (genial!) em todos os níveis (composição, arranjo, performance), Hermeto cria sua música organizadamente, pelo menos no seu monumental Calendário do som.
Recorrendo ao legado de Schoenberg sobre música tonal, vimos que a aparente aleatoriedade harmônica e formal da música de Hermeto pode ser explicada dentro dos diversos conceitos que gravitam em torno dos conceitos de Monotonalidade, Tonalidade Expandida e Variação Progressiva, os quais tratam, respectivamente, do afastamento e aproximação da tonalidade; suspensão e flutuação de regiões tonais; e da composição rapsódica a partir de unidades formais hierárquicas.

Nas formas livres de Hermeto Pascoal observamos uma abundância de Temas e Ideias contrastantes ou conectados, a utilização de Regiões remotas em curtos espaços de tempo, a utilização de "pontes" e justaposições abruptas" para gerar e controlar as tendências centrifugas da harmonia. Observamos também a recorrência de Gestaltes organizadas segundo o padrão da Forma Sentença (forma aberta), o que sugere um estilo composicional que é fruto de um processo gradual de variação de ideias básicas.

Após a análise formal e harmônica minuciosa das duas canções instrumentais de Hermeto, seguiu-se o processo de realização, no qual foram criadas linhas cromáticas e quase-diatônica para a realização dos afastamentos tonais para Regiões remotas ou manutenção da suspensão ou flutuação tonal. Depois, foram feitas intervenções na forma a partir da interpretação e manipulação dos elementos analisados e criados elementos de arranjo como choruses com convenções para os solos de piano e contrabaixo e, finalmente, se chegar às lead sheets de realização.

\section{3 de Junho de 1996}

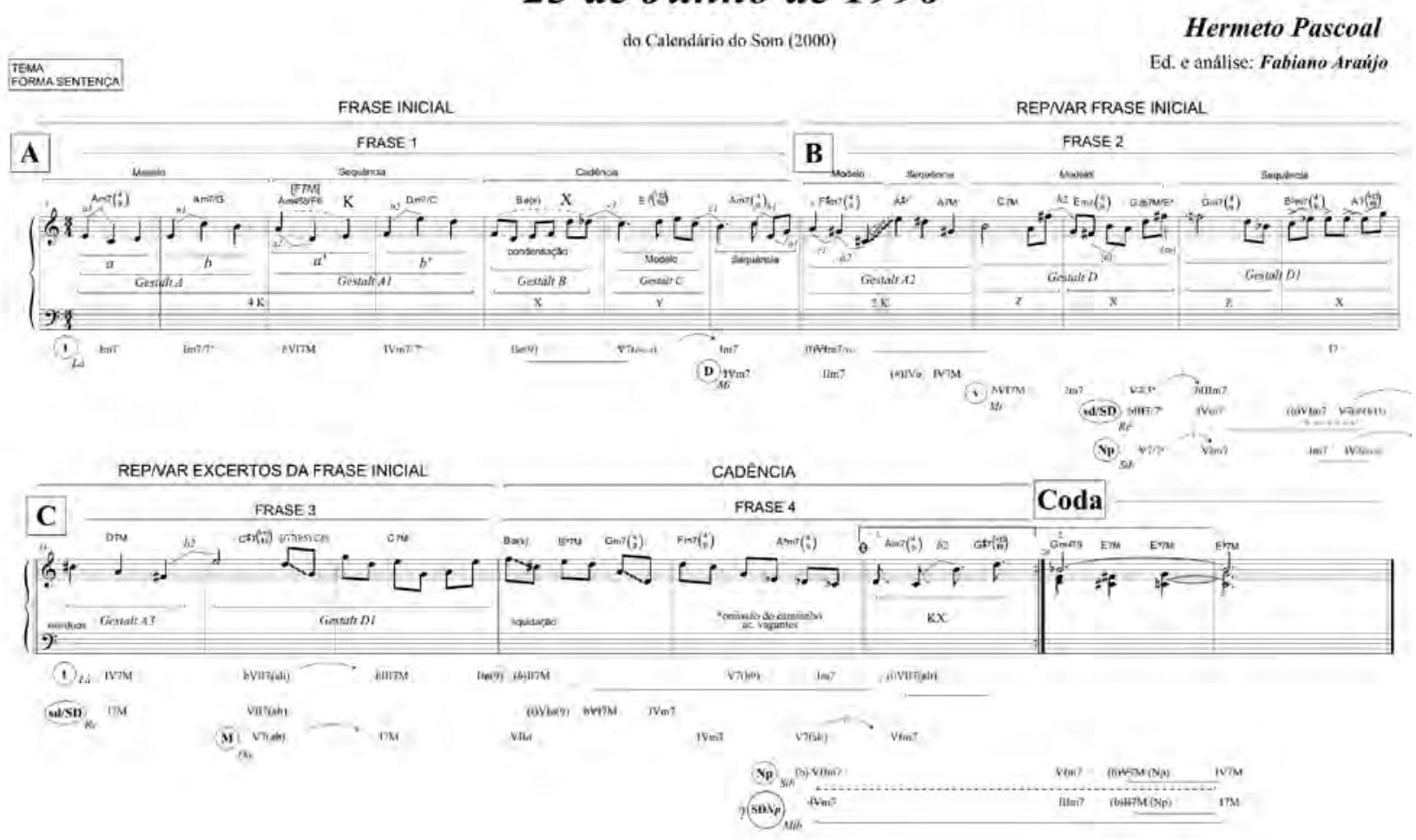

Ex.42 - Esquema analítico completo de 26 de Junho de 1996 de Hermeto Pascoal. 


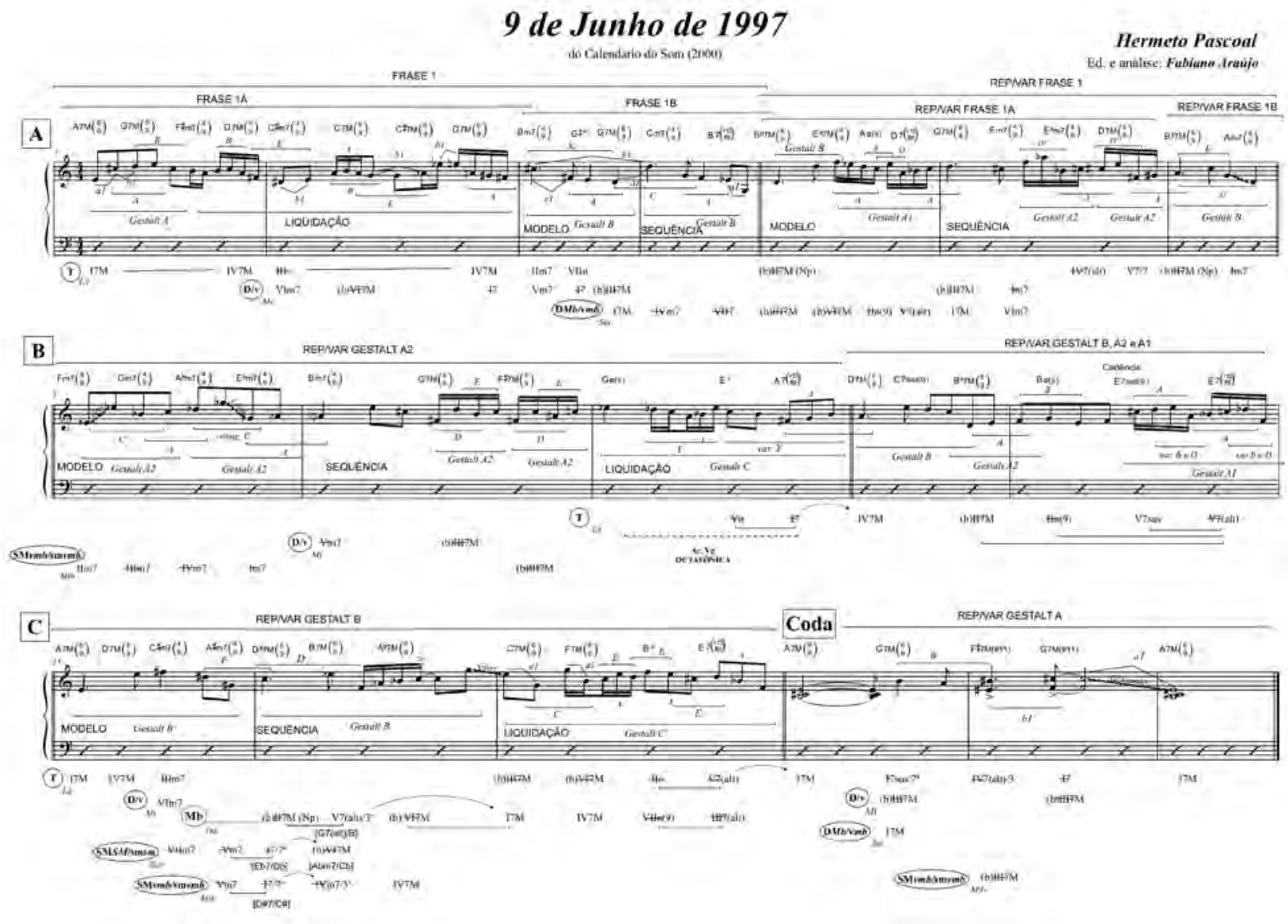

Ex.43 - Esquema analítico completo de 9 de Junho de 1997 de Hermeto Pascoal.

Esperamos que o presente artigo, juntamente com os anteriores, sirva de material didático no ensino da composição, arranjo e performance da música popular, não apenas de Hermeto Pascoal, mas de muito outros cuja música inspire empreitadas semelhantes. Registramos aqui a condução de um projeto de pesquisa desenvolvido pelo primeiro co-autor no Programa de Iniciação Científica da Universidade Federal do Espirito Santo (UFES), que levantou, até o momento, dados analíticos das 36 primeiras peças do Calendário do Som de Hermeto Pascoal a partir dos conceitos da Teoria Tonal de Schoenberg.
Talvez esteja na simplicidade da sabedoria do músico brasileiro a chave para compreender como a racionalidade alemã de Schoenberg se encaixa como uma luva para explicar o turbilhão tropical da música de Hermeto Pascoal, que ele apregoa no primeiro dos seus dezessete Princípios da Música Universal: "A Harmonia é a mãe da música, o ritmo é o pai e a melodia ou o tema é o filho" (PASCOAL, Princípios da Música Universal, 2012). 


\section{Referências:}

ARAÚJO, Fabiano; BORÉM, Fausto. A Harmonia tonal de Schoenberg: uma proposta para a análise, realização e composição de lead sheets. Per Musi. n.28. Belo Horizonte: UFMG, 2013. p.35-69.

BORÉM, Fausto; ARAÚJO, Fabiano. Hermeto Pascoal: experiência de vida e a formação de sua linguagem harmônica. Per Musi, n.22. Belo Horizonte: UFMG, 2010. p.22-43.

BORÉM, Fausto; FREIRE, Maurício. Cannon de Hermeto Pascoal: aspectos musicais e religiosos em uma obra-prima para flauta. Per Musi, n.22. Belo Horizonte: UFMG, 2010. p.63-79.

BUETTNER, Arno Roberto von. Expansão Harmônica: uma questão de timbre. São Paulo: Irmãos Vitale, 2004.

CUGNY, Laurent, Analyser le jazz. Paris: Outre Mesure, 2009.

DUDEQUE, Norton, E. Music Theory and Analysis in the Writings of Arnold Schoenberg (1874-1951). England: Ashgate, 2005.

Schoenberg e a Função Tonal. Revista Eletrônica de Musicologia. Dep. Artes da UFPR. v.2, n.1.1997.

Variação progressiva como um processo gradual no primeiro movimento do Quarteto A Dissonância, K 465, de Mozart. Per Musi. v.8, jul-dez. Belo Horizonte: UFMG, 2003. p.41-56.

FREIRE, Nelson; SALLES, João Moreira. Uma frustração. In: Nelson Freire: um filme sobre um homem e sua música (2003). Filme de João Moreira Salles, 2003. Vídeo de 01 hora, 36 minutos e 51 segundos, postado no Youtube por "Docspt Arte" em 16 de outubro de 2012. (2003. Acesso em 25 de janeiro 2013).

LEVINE, Marc, The jazz piano book. Berkeley: Sher Music,CO., 1989.

PASCOAL, Hermeto. 9 de Junho de 1997. In: Calendário do som. São Paulo: Editora Senac, 2000a. p.374. (Partitura musical em forma de lead sheet).

9 de Junho de 1997 (Calendário do som): manuscrito e lead sheet de realização. Realização e edição de Fabiano Araújo. Per Musi. n.28. Belo Horizonte: UFMG, 2013b. p.99-101.

23 de junho de 1996. In: Calendário do som. São Paulo: Editora Senac, 2000b. p.23. (Partitura musical em forma de lead sheet).

23 de junho de 1996 (Calendário do som): manuscrito e lead sheet de realização. Realização e edição de Fabiano Araújo. Per Musi. n.28. Belo Horizonte: UFMG, 2013a. p.96-99.

Princípios da Música Universal criada por Hermeto Pascoal. Ed. de Aline Morena. Partituras. Curitiba: 30 de setembro de 2008. In: www.hermetopascoal.com.br (Manuscrito escaneado, acesso em 24 de dezembro, 2012).

SALZER, Felix. Structural Hearing, Tonal Coherence in Music. New York: Dover Publications. 1982 [1952].

SCHOENBERG, Arnold. Style and Idea. Trans. Leo Black. Ed. Leonard Stein. University of California Press, 1984 [1975]. . Fundamentos da Composição Musical. Trad. Eduardo Seincman, 2 ed. São Paulo: Editora da Universidade de São Paulo, 1993 [1967].

Coherence, counterpoint, instrumentation, instruction in form. Trad. Charlotte M. Cross e Severine Neff. Publicado anteriormente em 1917. Ed.Severine Neff. Lincoln: University of Nebraska Press:Lincoln, 1994. . Harmonia. Trad. Marden Maluf. São Paulo: Editora UNESP, 1999 [1911]. Exercícios Preliminares em Contraponto. Trad. Eduardo Seincman, Ed. Leonard Stein. São Paulo: Via Lettera, 2001 [1963].

Funções estruturais da harmonia. Trad. de Eduardo Seincman, Ed. Leonard Stein. São Paulo: Via Lettera, 2004 [1969].

The Musical Idea and the logic, technique and art of its presentation. Publicado anteriormente em 1995. Ed. de Patricia Carpenter e Severine Neff. Bloomington: Indiana University Press, 2006.

ZAGO, Luis Gustavo. Composição e improvisação no Calendário do Som. em Repom no 4, Julho de 2007. Disponível na

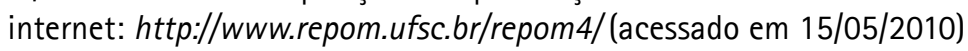

\section{Referências de gravações}

PASCOAL, Hermeto. Calendário do som: 9 dias. Fabiano Araújo, piano; Arild Andersen, contrabaixo; Alexandre Frazão, bateria; Guto Lucena, saxofone. Numérica: NUM 1185, 2009. Disponível em: $<$ http://www.myspace.com/fabianoaraujo >. 
Notas

1 Veja item 4.3.1 - Procedimentos de Expansão Harmônica em ARAUJO e BORÉM (2013) às p.58-62. desse número de Per Musi).

2 Idem (Veja item 4.3.1).

3 Essa analogia é usada por Schoenberg ao explicar o uso de acordes provenientes das relações com a subdominante menor, quando a narrativa requer enlaces mais fluidos entre as partes: "Luzes mais penetrantes, sombras mais obscuras: a isso também servem esses acordes mais distantes (SCHOENBERG 1999, p.325)."

4 Veja também item 2.5.2 - Regiões Tonais Intermediárias em ARAUJO e BORÉM (2013) às p.44-45. desse número de Per Musi).

5 Veja item 3.3 - Função de Acordes Vagantes (ou de Função Múltipla) em ARAUJO e BORÉM (2013) à p.52. desse número de Per Musi).

6 Veja item 2.3 - Conceito de Notas Substitutas/Substituição em ARAUJO e BORÉM (2013) à p.40. desse número de Per Musi).

Fabiano Araújo, pianista e compositor, desenvolve tese de doutorado sobre o jazz contemporâneo, desde 2012, na Universidade Paris-Sorbonne (Paris-IV), com bolsa CAPES, junto ao grupo JCMP-OMF (Jazz, chanson et musiques populaires - Observatoire Musical Français). É Mestre em Música pela Escola de Música da UFMG e Bacharel em Música Popular pelo Centro de Artes da UNICAMP. É Professor Assistente do Centro de Artes da Universidade Federal do Espírito Santo (UFES), onde contribuiu para a criação o curso de Bacharelado em Música, habilitação em Composição com ênfase em Trilha Musical. Possui 4 CD's lançados: O Aleph (2007); Calendário do Som - 9 dias (2009) de Hermeto Pascoal, gravado e publicado em Portugal, com a participação do contrabaixista norueguês Arild Andersen do baterista Alexandre Frazão (Brasil/Portugal) e do saxofonista Guto Lucena (Brasil/Portugal); Rheomusi (2011) em trio com Arild Andersen e Naná Vasconcelos, e Baobab trio (2012), com peças de Radamés Gnattali, Baden Powell além de música improvisada em trio.

Fausto Borém é Professor Titular da Escola de Música da Universidade Federal de Minas Gerais (UFMG), onde criou o Mestrado e a Revista Per Musi. É pesquisador do CNPq desde 1994 e seus resultados de pesquisa incluem um livro, três capítulos de livro, dezenas de artigos sobre práticas de performance e suas interfaces (composição, análise, musicologia, etnomusicologia e educação musical) em periódicos nacionais e internacionais, dezenas de edições de partituras e recitais nos principais eventos nacionais e internacionais de contrabaixo. Recebeu diversos prêmios no Brasil e no exterior como solista, teórico, compositor e professor. Acompanhou músicos eruditos como Yo-Yo Ma, Midori, Menahen Pressler, Yoel Levi, Arnaldo Cohen e músicos populares como Hermeto Pascoal, Egberto Gismonti, Henry Mancini, Bill Mays, Kristin Korb, Grupo UAKTI, Toninho Horta, Juarez Moreira, Tavinho Moura, Roberto Corrêa e Túlio Mourão. Participou do CD e DVD $O$ Aleph de Fabiano Araújo Costa. 